Prepared in cooperation with the U.S. Department of the Army Environmental and Natural Resources Management Office of the U.S. Army Signal Center and Fort Gordon

\title{
Assessment of Soil-Gas, Seep, and Soil Contamination at the North Range Road Landfill, Fort Gordon, Georgia, 2008-2009
}

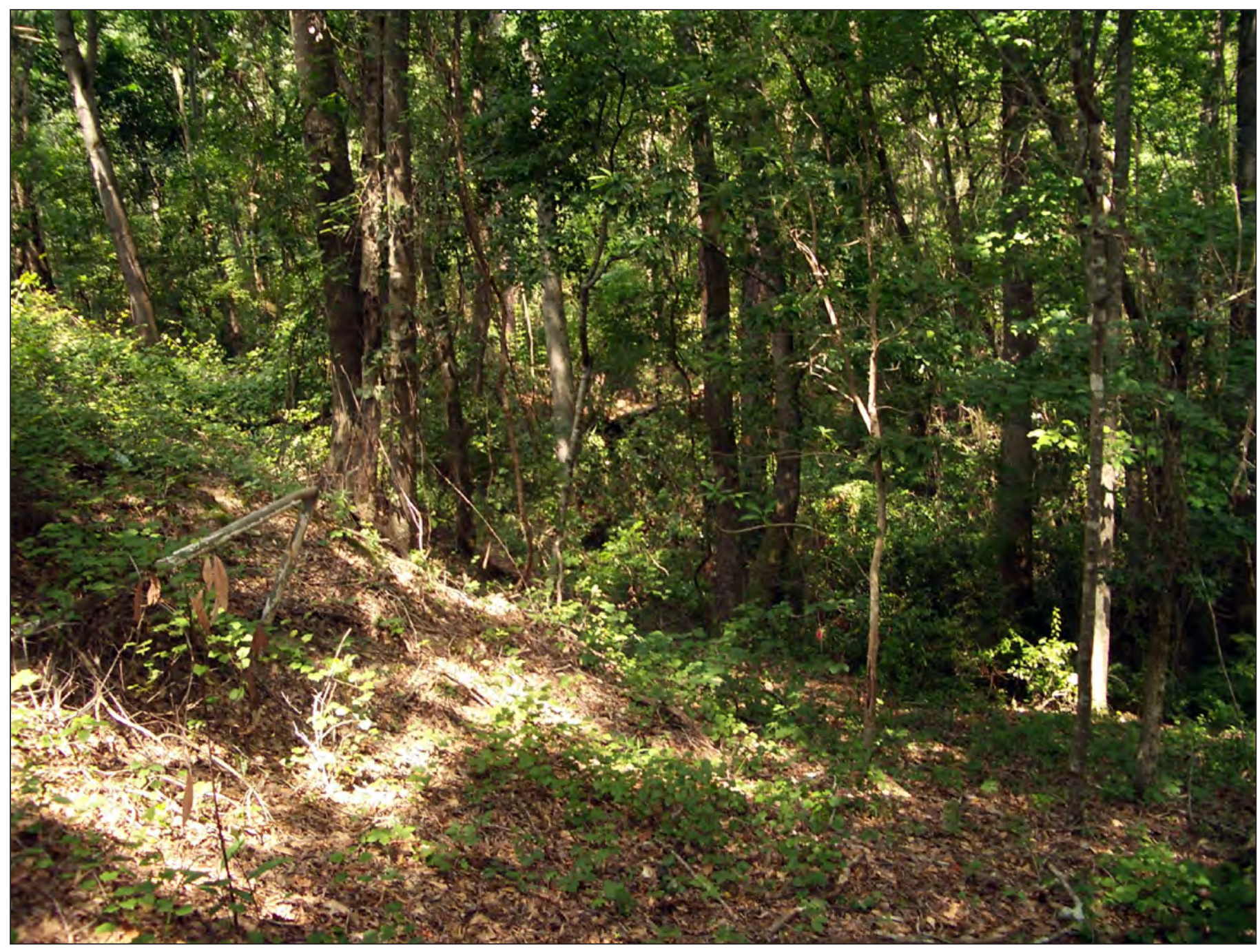

Open-File Report 2011-1043 
Cover photograph: Exposed metal waste (left foreground) and the location of a soil-gas sampler (pink flag, right background) at North Range Road Landfill, Fort Gordon, Georgia. 


\section{Assessment of Soil-Gas, Seep, and Soil Contamination at the North Range Road Landfill, Fort Gordon, Georgia, 2008-2009}

By James E. Landmeyer, William F. Falls, W. Hagan Ratliff, and John B. Wellborn

Prepared in cooperation with the U.S. Department of the Army Environmental and Natural Resources Management Office of the U.S. Army Signal Center and Fort Gordon

Open-File Report 2011-1043 


\section{U.S. Department of the Interior \\ KEN SALAZAR, Secretary}

\section{U.S. Geological Survey \\ Marcia K. McNutt, Director}

U.S. Geological Survey, Reston, Virginia: 2011

For more information on the USGS - the Federal source for science about the Earth, its natural and living resources, natural hazards, and the environment, visit http://www.usgs.gov or call 1-888-ASK-USGS

For an overview of USGS information products, including maps, imagery, and publications,

visit http://www.usgs.gov/pubprod

To order this and other USGS information products, visit http://store.usgs.gov

Any use of trade, product, or firm names is for descriptive purposes only and does not imply endorsement by the U.S. Government.

Although this report is in the public domain, permission must be secured from the individual copyright owners to reproduce any copyrighted materials contained within this report.

Suggested citation:

Landmeyer, J.E., Falls, W.F., Ratliff, W.H., and Wellborn, J.B., 2011, Assessment of soil-gas, seep, and soil contamination at the North Range Road Landfill, Fort Gordon, Georgia, 2008-2009: U.S. Geological Survey Open-File Report 2011-1043, 21 p. 


\section{Contents}

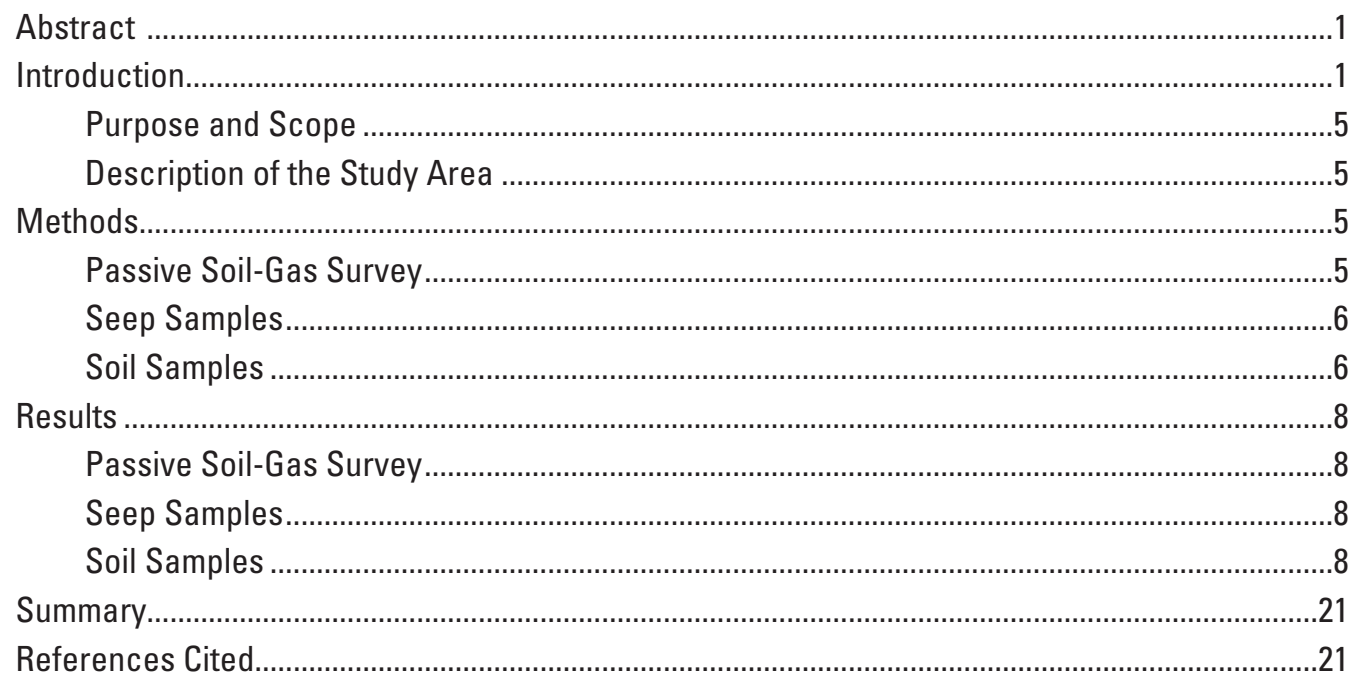

\section{Figures}

1. Map showing location of North Range Road Landfill, Fort Gordon, Georgia

2. Map showing location of the generalized study area of North Range Road Landfill and the three seeps, exposed metal waste, and the approximate extent of buried waste at North Range Road Landfill, Fort Gordon, Georgia

3. Photographs of one of several Gore ${ }^{\mathrm{TM}}$ modules used for the passive soil-gas survey at Fort Gordon, Georgia, and a module that has been retrieved and prepared for shipping to the laboratory for analysis

4-7. Maps showing -

4. Locations of 3 seeps and 29 soil-gas sampling sites at the North Range Road Landfill, Fort Gordon, Georgia, 2008-2009

5. Detections of total petroleum hydrocarbon mass in 29 soil-gas samplers installed at the North Range Road Landfill, Fort Gordon, Georgia, 2008-2009

6. Detections of benzene, toluene, ethylbenzene, and xylenes mass in 11 soil-gas samplers installed at the North Range Road Landfill, Fort Gordon, Georgia, 2008-2009

7. Detections of perchloroethylene mass in five soil-gas samplers installed at the North Range Road Landfill, Fort Gordon, Georgia, 2008-2009. 


\section{Tables}

1. Mass of volatile organic compounds detected in soil-gas samples collected from the North Range Road Landfill, Fort Gordon, Georgia, 2008-2009

2. Organic compounds detected in groundwater discharge from the seeps, collected July 27, 2009.

3. Semivolatile organic compounds detected in groundwater discharge from the seeps, collected July 27, 2009

4. Inorganic constituents detected in groundwater discharge from the seeps, collected July 27, 2009.

5. Inorganic constituents detected in soil, land surface to 24 inches, collected July 27, 2009.

\section{Conversion Factors}

Inch/Pound to SI

\begin{tabular}{|c|c|c|}
\hline Multiply & By & To obtain \\
\hline \multicolumn{3}{|c|}{ Length } \\
\hline inch (in.) & 2.54 & centimeter $(\mathrm{cm})$ \\
\hline inch (in.) & 25.4 & millimeter (mm) \\
\hline foot & 0.3048 & meter (m) \\
\hline mile (mi) & 1.609 & kilometer (km) \\
\hline \multicolumn{3}{|c|}{ Area } \\
\hline acre & 4,047 & square meter $\left(\mathrm{m}^{2}\right)$ \\
\hline acre & 0.4047 & hectare (ha) \\
\hline acre & 0.4047 & square hectometer $\left(\mathrm{hm}^{2}\right)$ \\
\hline acre & 0.004047 & square kilometer $\left(\mathrm{km}^{2}\right)$ \\
\hline
\end{tabular}

Horizontal coordinate information is referenced to the North American Datum of 1983 (NAD 83). 


\section{Selected acronyms and abbreviations used in this report include:}

$\begin{array}{ll}\text { BTEX } & \text { Benzene, toluene, ethylbenzene, and xylene (total) } \\ \text { GC/MS } & \text { Gas chromatography/mass spectroscopy } \\ \text { GLPS } & \text { Good Laboratory Practices Standards } \\ \text { MCL } & \text { Maximum contaminant level } \\ \text { MDL } & \text { Method detection level } \\ \text { MTBE } & \text { Methyl tert-butyl ether } \\ \mu \mathrm{g} & \text { Microgram } \\ \mu \mathrm{g} / \mathrm{g} & \text { Microgram per gram } \\ \mu \mathrm{g} / \mathrm{L} & \text { Microgram per liter } \\ \mathrm{mg} / \mathrm{kg} & \text { Milligram per kilogram } \\ \mathrm{mL} & \text { Milliliter } \\ \text { NPDWS } & \text { National Primary Drinking Water Standard } \\ \text { NRLF } & \text { North Range Road Landfill } \\ \text { NSDWS } & \text { National Secondary Drinking Water Standard } \\ \text { PAH } & \text { Polycyclic aromatic hydrocarbon } \\ \text { PCE } & \text { Perchloroethylene (also known as tetrachloroethylene) } \\ \text { RCRA } & \text { Resource Conservation and Recovery Act } \\ \text { RSL } & \text { Regional screening level } \\ \text { SVOC } & \text { Semivolatile organic compound } \\ \text { SC DHEC } & \text { South Carolina Department of Health and Environmental Control } \\ \text { TCE } & \text { Trichloroethylene } \\ \text { TPH } & \text { Total petroleum hydrocarbon } \\ \text { USEPA } & \text { U.S. Environmental Protection Agency } \\ \text { USGS } & \text { U.S. Geological Survey } \\ \text { VOC } & \text { Volatile organic compound } \\ \end{array}$





\title{
Assessment of Soil-Gas, Seep, and Soil Contamination at the North Range Road Landfill, Fort Gordon, Georgia, 2008-2009
}

\author{
By James E. Landmeyer, ${ }^{1}$ William F. Falls, ${ }^{1}$ W. Hagan Ratliff, ${ }^{2}$ and John B. Wellborn ${ }^{3}$
}

\section{Abstract}

Soil gas, seeps, and soil were assessed for contaminants at the North Range Road Landfill at Fort Gordon, Georgia, from October 2008 to September 2009. The assessment included delineating organic contaminants present in soil-gas samples beneath the area estimated to be the landfill and in water samples collected from three seeps at the base of the landfill. Inorganic contaminants were determined in three seep samples and in soil samples. This assessment was conducted to provide environmental contamination data to Fort Gordon pursuant to requirements for the Resource Conservation and Recovery Act Part B Hazardous Waste Permit process.

All soil-gas samples collected contained total petroleum hydrocarbons above the method detection level. The highest total petroleum hydrocarbon mass detected was nearly 50 micrograms $(\mu \mathrm{g})$ in a soil-gas sample from one of the three seeps. The highest BTEX mass detected was $0.83 \mu \mathrm{g}$ in a soil-gas sample collected near the same seep. Some soil-gas samples had perchloroethylene (known as PCE) mass greater than the method detection level of 0.01 microgram. The highest PCE mass detected was $0.73 \mu \mathrm{g}$, and PCE mass was detected in soil gas in areas upgradient of the seeps and indicates that the seep contamination may be related to previous waste-disposal activities upgradient of the seeps.

No organic or semivolatile compounds in the seep samples were detected above their respective maximum contaminant levels established in the U.S. Environmental Protection Agency National Primary Drinking Water Standards. PCE was detected in water from all three seeps at concentrations between 0.85 and 0.95 microgram per liter. Trimethylsilanol was detected in water collected from all three seeps and may be related to the degradation of silicone-based materials commonly disposed of in landfills.

Inorganic concentrations in water samples from one seep did not exceed any maximum contaminant levels in the

${ }^{1}$ U.S. Geological Survey, Columbia, South Carolina.

${ }^{2}$ Environmental Branch, Fort Gordon, Georgia.

${ }^{3}$ Environmental and Natural Resources Division, Fort Gordon, Georgia.
National Secondary Drinking Water Standards. In water from one seep, however, iron was detected at 865 micrograms per liter, which exceeds the maximum contaminant level for iron in the Secondary Drinking Water Standard, and in water from the other seep, iron and manganese were detected at 492,000 and 10,700 micrograms per liter, repectively, both of which exceed the respective maximum contaminant levels for the Secondary Drinking Water Standard. Water from one of the seeps had concentrations of cadmium, copper, and zinc that exceed Georgia standards for in-stream water quality, and concentrations of arsenic and lead that exceed their respective maximum contaminant levels for the Primary Drinking Water Standards.

Inorganic concentrations in all four soil samples did not exceed regional screening levels established by the U.S. Environmental Protection Agency. Barium concentrations, however, were two to three times higher than the background concentrations reported in similar Coastal Plain sediments of South Carolina.

\section{Introduction}

Fort Gordon is a U.S. Department of the Army facility located approximately 10 miles southwest of Augusta in eastcentral Georgia (fig. 1). In 2001 an abandoned landfill was discovered at the bottom of steeply sloping topography adjacent to the intersection of Range and North Range Roads on Fort Gordon (fig. 1); this landfill is called the North Range Road Landfill (NRLF). The approximately 3-acre NRLF (fig. $2 A$ ) was believed to have been used to dispose of wastes generated during construction activities that occurred in the 1960s and 1970s at Fort Gordon (AMEC Earth \& Environmental, Inc., written commun., November 2007). Some waste material is exposed at land surface along the slope and includes metal, wiring, and sheet metal (fig. $2 B$ ). Most of the waste materials, however, appear to be buried beneath a thick accumulation of leaf litter and sediments eroded from upgradient areas. This accumulation of natural material has resulted in the establishment and growth of small trees and understory vegetation over most of the NRLF. 

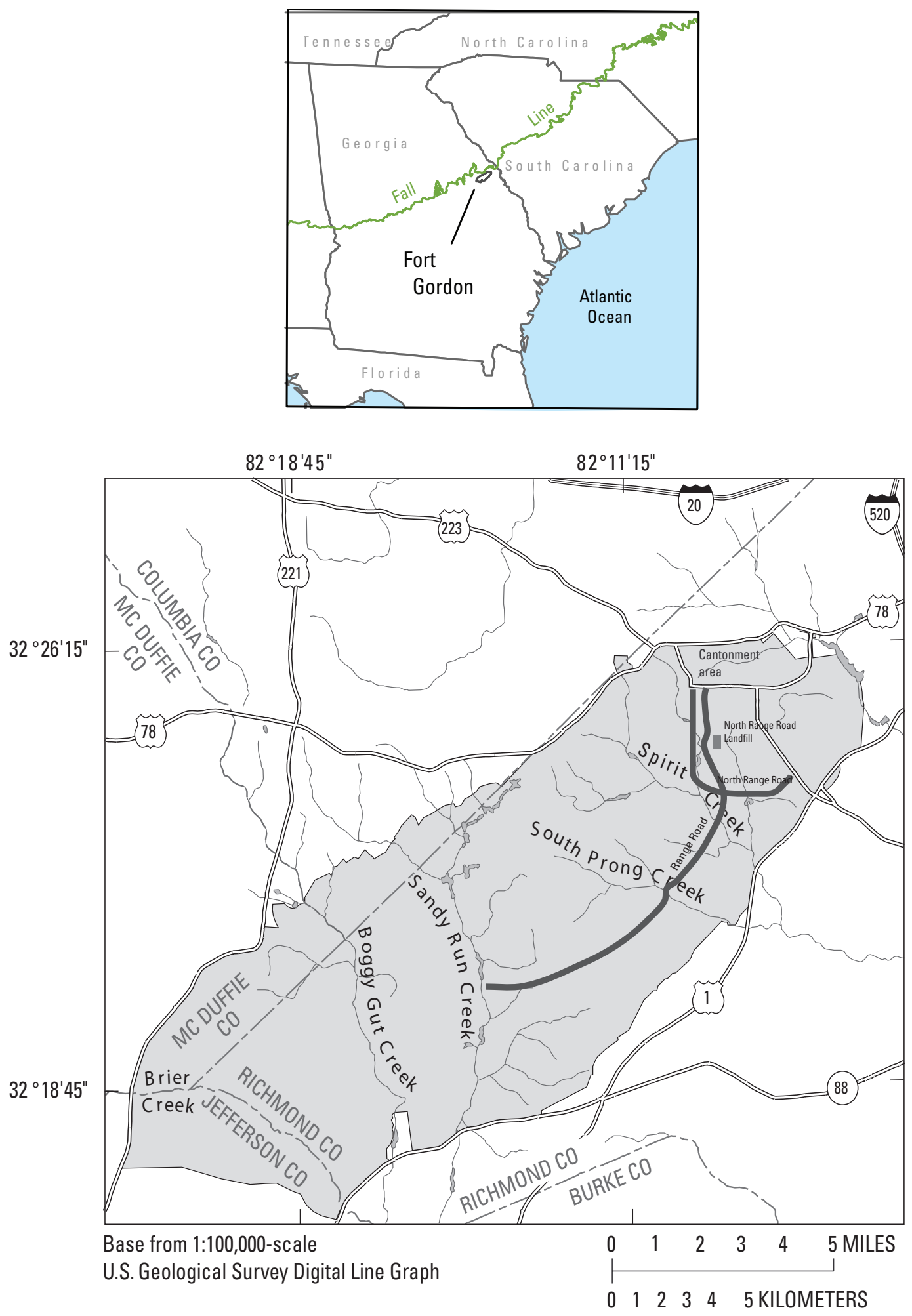

EXPLANATION

NORTH RANGE ROAD LANDFILL

FORT GORDON

Figure 1. Location of North Range Road Landfill, Fort Gordon, Georgia. 


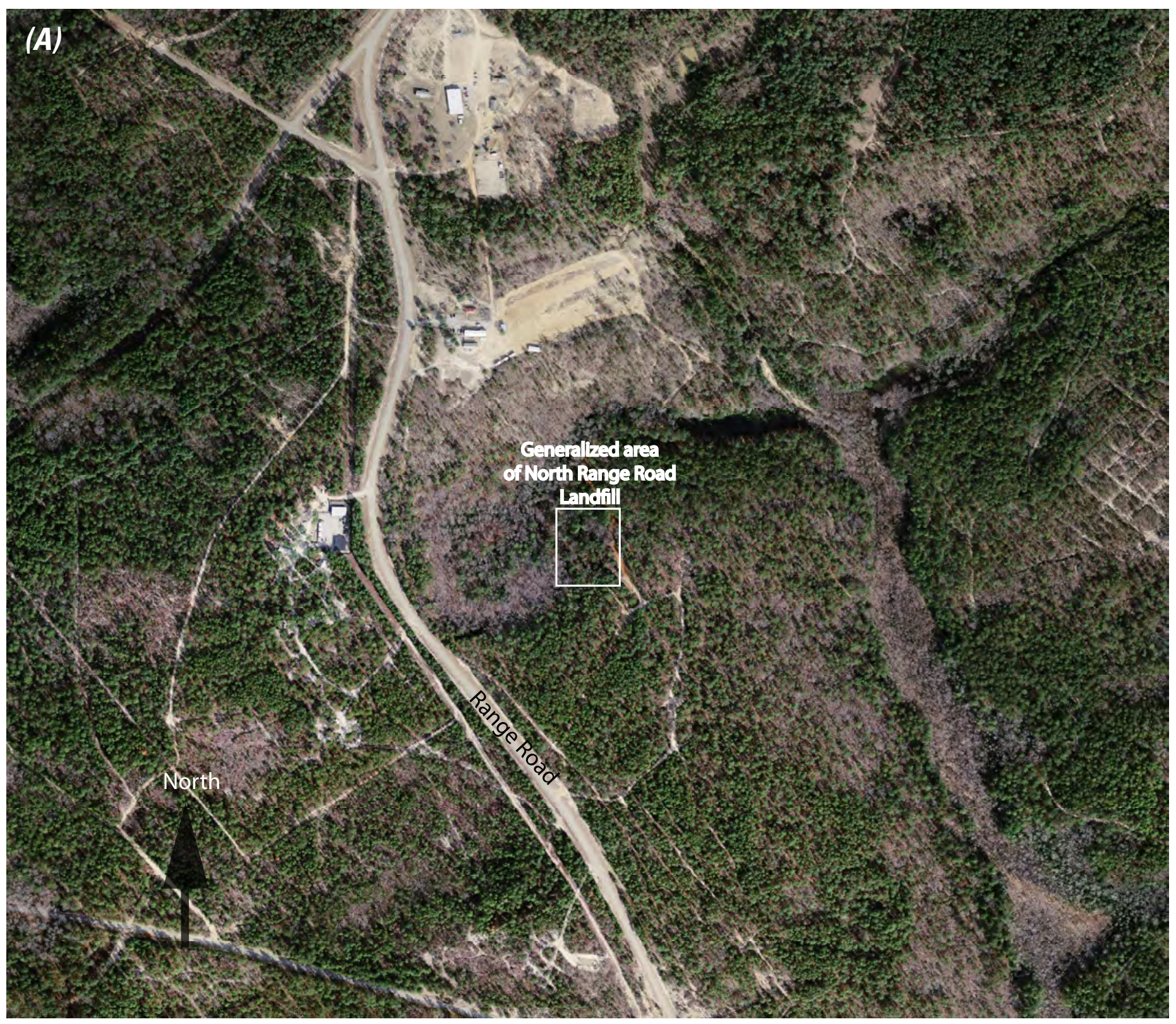

From U.S. Geological Survey digital data

Figure 2. Location of $(A)$ the generalized study area of North Range Road Landfill and $(B)$ the three seeps, exposed metal waste, and the approximate extent of buried waste at North Range Road Landfill, Fort Gordon, Georgia. 


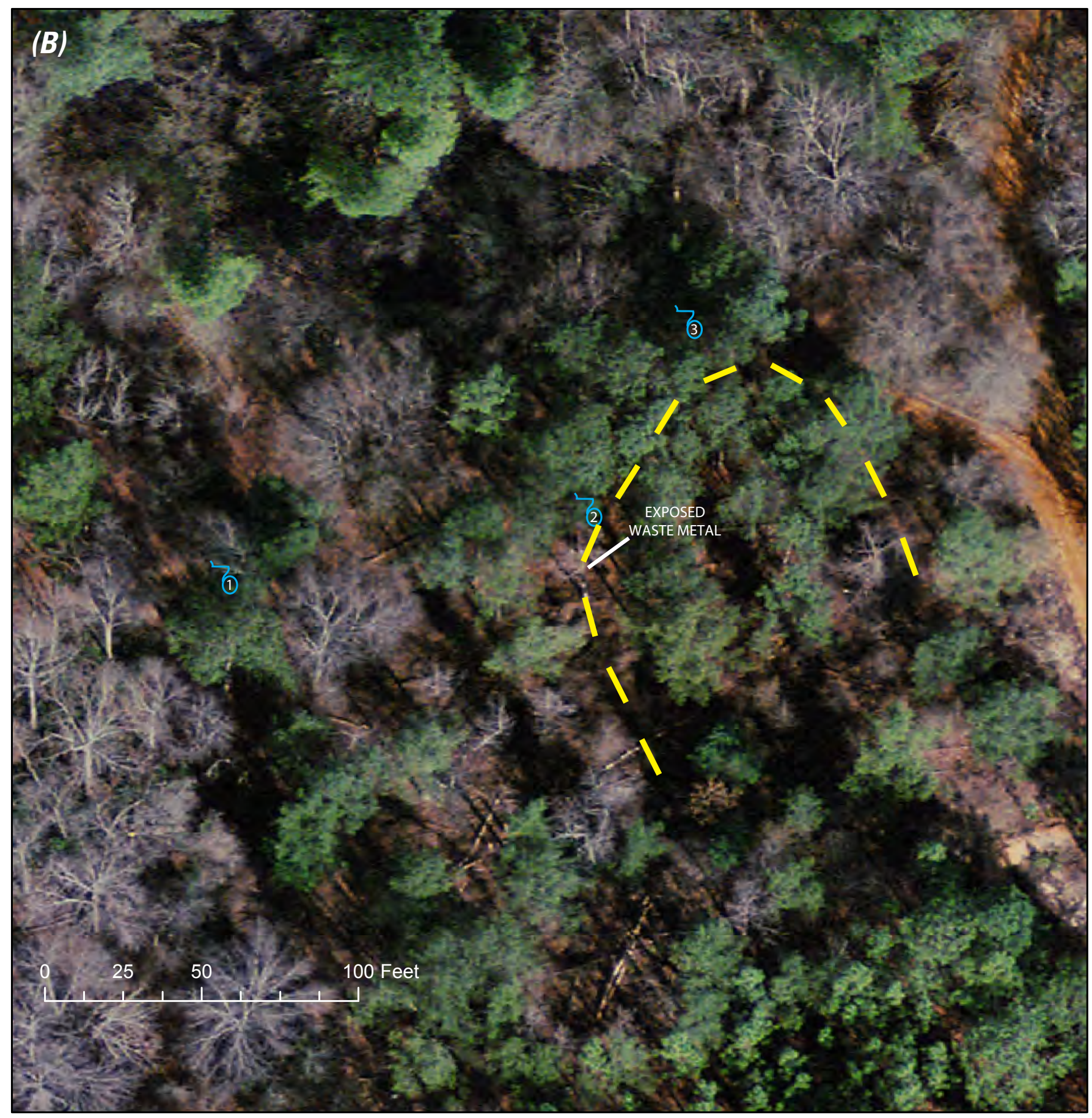

From U.S. Geological Survey digital data

EXPLANATION

APPROXIMATE EXTENT OF BURIED WASTES
(1) SEEP AND NUMBER

Figure 2. Location of $(A)$ the generalized study area of North Range Road Landfill and $(B)$ the three seeps, exposed metal waste, and the approximate extent of buried waste at North Range Road Landfill, Fort Gordon, Georgia._Continued 
The downgradient and down-slope boundary of the NRLF coincides with at least three seeps, or areas of low altitude characterized by groundwater discharge (fig. $2 B$ ). In September 2007, initial sampling of the water quality of the eastern-most seep was reported to contain concentrations of chlorobenzene, cis-1,2-dichloroethene, 1,2-dichlorobenzene, 1,1-dichloroethane, vinyl chloride, barium, chromium, iron, manganese, and zinc that exceeded the analytical reporting level for each compound and element (sample location RSW2S [seep 3 in this report]; AMEC Earth \& Environmental, Inc., written commun., November 2007). All compound detections, however, were at concentrations below the U.S. Environmental Protection Agency's (USEPA) maximum contaminant level (MCL) for National Primary Drinking Water Standards (NPDWS) and Georgia's In-Stream Water-Quality Standard (ISWQS; Georgia Department of Natural Resources, 2007).

\section{Purpose and Scope}

From October 2008 to September 2009, the U.S. Geological Survey (USGS) in cooperation with the U.S. Department of the Army (U.S. Army) Environmental and Natural Resources Management Office of the U.S. Army Signal Center and Fort Gordon, assessed soil gas, seeps, and soil at the NRLF for contaminants. This assessment was conducted to provide environmental contamination data to the U.S. Army at Fort Gordon. The assessment included the delineation of organic contaminants present in soil-gas samples beneath the NRLF and in water samples collected from three seeps. The assessment also included the delineation of inorganics in soil samples. This report presents the analytical results of the soilgas, seep, and soil samples and delineates the area of contamination in the study area.

\section{Description of the Study Area}

Fort Gordon is a U.S Army facility located approximately 10 miles southwest of Augusta in east-central Georgia (fig. 1). The Fort lies in the northern part of the Coastal Plain Physiographic Province just south of the Fall Line. Surficial soil and sediment are characterized by unconsolidated sands, indurated sands and semi-consolidated sandstones, and layers of clay that include kaolinite (Gregory and others, 2001; Williams, 2007).

\section{Methods}

The methods to assess the contamination at the NRLF were selected to provide data to determine the presence or absence of contamination of soil-gas, seep, and surficial soil. The soil-gas method provides results that are qualitative, and the seep and soil samples provide quantitative data that can be compared to standards.

\section{Passive Soil-Gas Survey}

The assessment of soil-gas contamination was conducted using a passive soil-gas survey based on the Gore ${ }^{\mathrm{TM}}$ Module, a commercially available medium based on GORE-TEX ${ }^{\circledR}$ membrane technology (U.S. Environmental Protection Agency, 1998; W.L. Gore \& Associates, Inc., 2004; ASTM International, 2006). The module is an adsorbent material inside a shoestring-shaped GORE-TEX ${ }^{\circledR}$ tube (fig. $3 A$ ). The material can adsorb a wide variety of volatile organic compounds (VOCs), including solvents such as perchloroethylene (PCE; also known as tetrachloroethylene); trichloroethylene (TCE); benzene, toluene, ethylbenzene, and xylenes (collectively referred to as BTEX); methyl tert-butyl ether (MTBE); semivolatile organic compounds (SVOCs); total petroleum hydrocarbons (TPH); and polycyclic aromatic hydrocarbons (PAHs), such as naphthalene. The modules were tied to a string, attached to a cork plug to prevent the entrance of surface water and ambient surface sources of contamination, and inserted into a shallow borehole. After 10 to 14 days, the modules were removed from the field, placed in 20-milliliter $(\mathrm{mL})$ gas-tight vials (fig. $3 B$ ), and sent to a commercial laboratory (W.L. Gore \& Associates, Inc.) for analysis by gas chromatography/ mass spectroscopy using a modification of USEPA method $8260 / 8270$ to include thermal desorption of the sample. The laboratory is in compliance with Good Laboratory Practices Standards (GLPS; U.S. Environmental Protection Agency, 2009a) and ISO Guide 25 (International Organization for Standardization, 1990). The soil-gas contaminant results are expressed as mass of contaminant (micrograms) and provide qualitatitve screening-level data.

Passive soil-gas results can indicate the presence of particular contaminants. The results, however, do not reveal whether the detection was derived from free product, from residual-phase adsorbed material or vapors in the unsaturated zone, or from the dissolved-phase in shallow and deep groundwater (unless the module is placed in water). In general, higher soil-gas mass in a sample tends to be related to the presence of residual contamination or free product that is close to the land surface where the soil-gas sampler is located. If such source material is located at greater depths, however, the soil-gas contaminant mass generally will be lower. A lower value near known sources may be due to various attenuation processes that affect the soil-gas mass prior to detection. In both cases, however, the modules help to rapidly indicate the presence or absence of contaminants. The passive soil-gas approach was approved for use at Fort Gordon by the Hazardous Waste Management Branch, Georgia Environmental Protection Department (William Powell, P.E., Environmental Engineer, Department of Defense Remediation Unit, oral commun., December 10, 2008).

A passive soil-gas survey was conducted at the NRLF during June 2009, when 29 soil-gas samplers (modules) were deployed (fig. 4). The soil-gas samplers were placed in the three seeps, and at locations across the generalized area of the NRLF and at increasing distances from the seeps. Two 
(A)

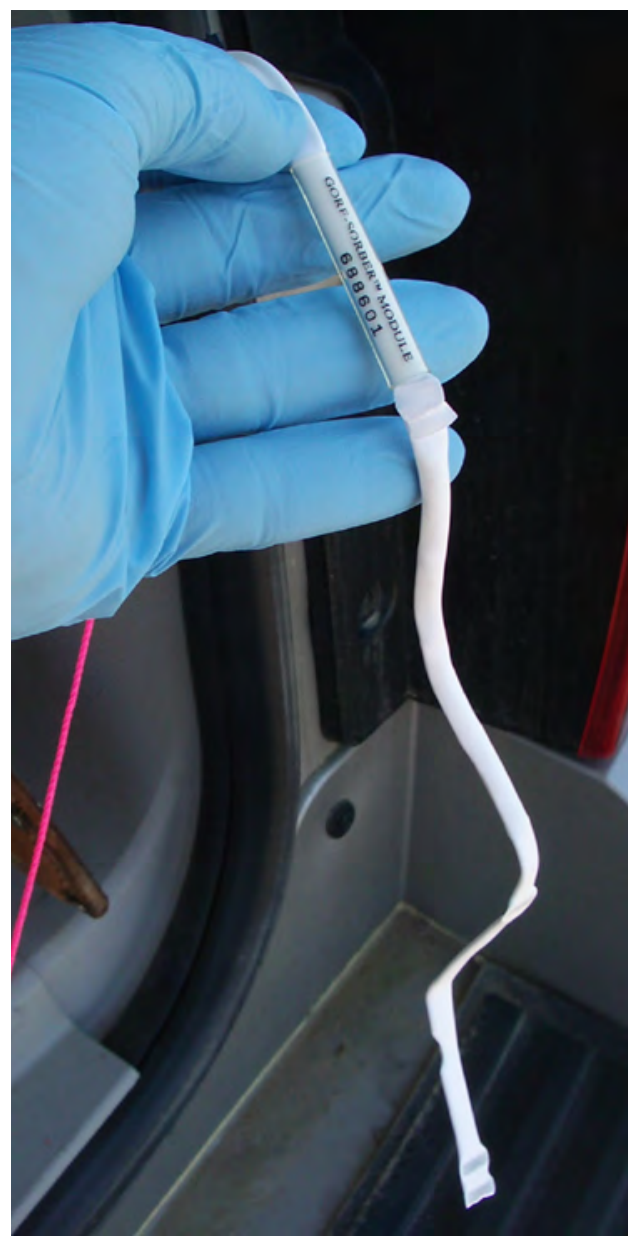

(B)

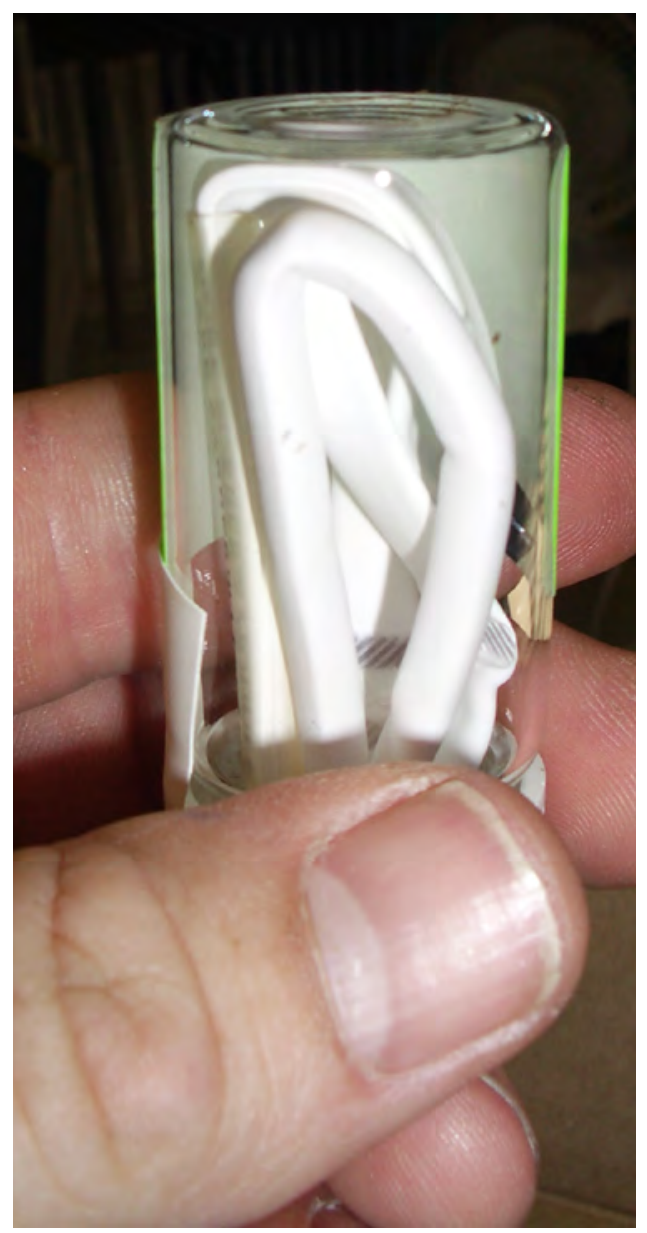

Figure 3. Photographs of $(A)$ one of several Gore ${ }^{T M}$ modules used for the passive soil-gas survey at Fort Gordon, Georgia, and $(B)$ a module that has been retrieved and prepared for shipping to the laboratory for analysis

additional soil-gas samplers were used as trip-blank samples and were not deployed. Each sampler was placed in a borehole that was 2.5 centimeter $(\mathrm{cm})$ in diameter and $75 \mathrm{~cm}$ long, created by a stainless steel ship-auger attached to a cordless drill. This depth is similar to that recommended by the USEPA for soil-gas investigations (U.S. Environmental Protection Agency, 1998). The auger was cleaned with a paper towel between each drilling. The 29 modules were installed on June 24, 2009, removed on July 16, 2009, placed in 20-mL gas-tight vials, and sent to the W.L. Gore \& Associates, Inc., laboratory for analysis.

\section{Seep Samples}

A water-quality sample was collected from each of the three seeps at the NRLF. To collect the sample, a $40-\mathrm{mL}$ volatile organic analysis (VOA) vial was submerged beneath the water surface where the seep emanated from the land surface, filled with water, acidified with hydrochloric acid, and then capped. The seep samples represent the discharge of groundwater that may have been in contact with the waste material beneath the NRLF. The water samples were analyzed for 85 VOCs, 18 SVOCs (such as PAHs), and 22 inorganics.

\section{Soil Samples}

Composite soil samples were collected using a stainlesssteel hand auger on July 27, 2009, at 6-inch (in.) intervals to a depth of 2 feet (ft). The soil samples were analyzed for 37 inorganics. Soil-sample concentrations were compared to USEPA regional screening levels (RSLs) for industrial soils (U.S. Environmental Protection Agency, 2009b) to determine the extent of contamination. Soil-sample metal concentrations also were compared to values for ambient, uncontaminated (background) levels for soils across the adjacent State of South Carolina (South Carolina Department of Health and Environmental Control, 2002) because no similar values were available for the State of Georgia. The comparison should be valid because the geologic features of Georgia and South Carolina are similar and both States share similar physiographic provinces. 


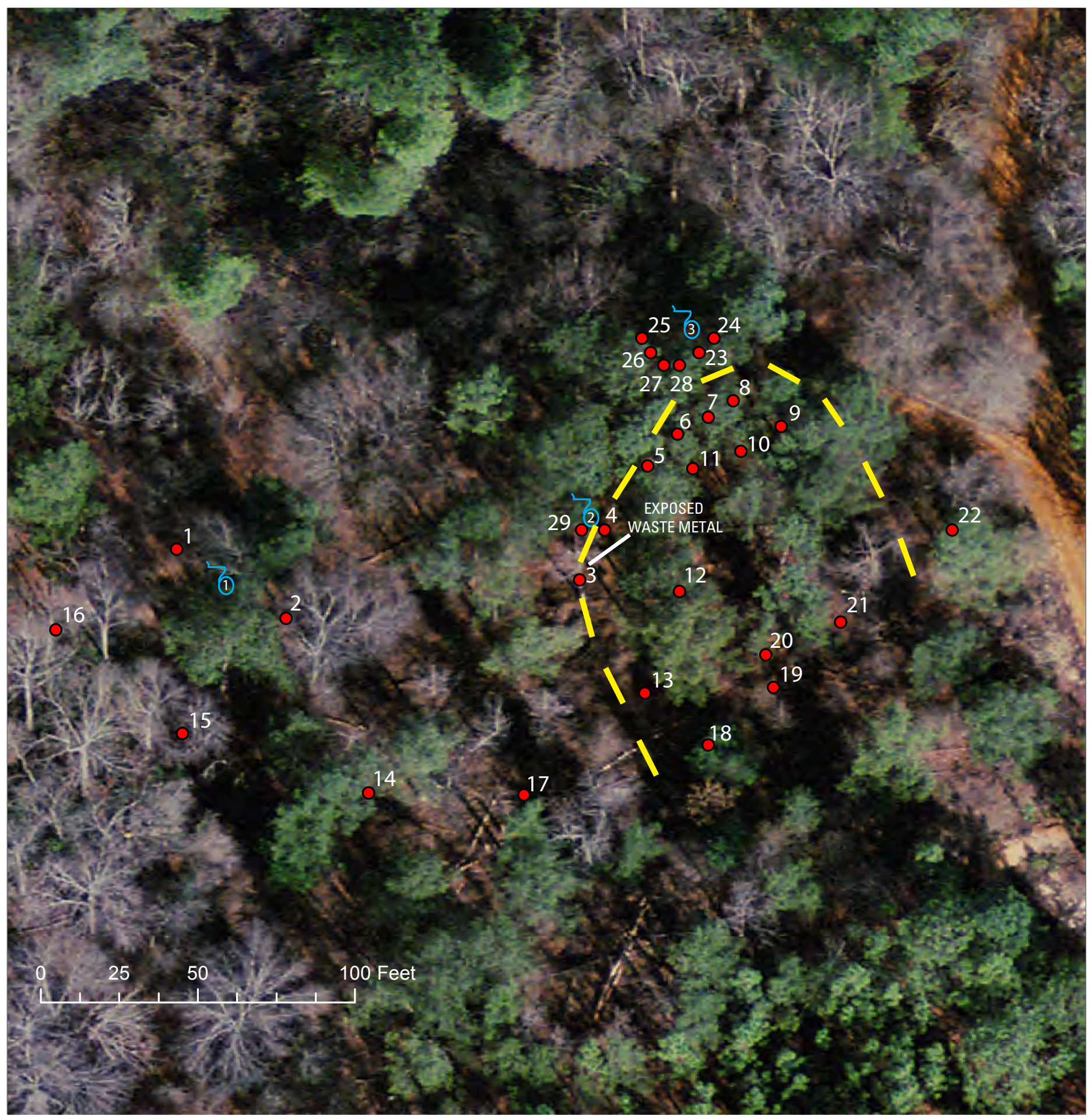

From U.S. Geological Survey digital data

\section{EXPLANATION}

APPROXIMATE EXTENT OF BURIED WASTES
(1) SEEP AND NUMBER
$0^{1}$ SOIL-GAS SAMPLER LOCATION AND IDENTIFIER

Figure 4. Locations of 3 seeps and 29 soil-gas sampling sites at the North Range Road Landfill, Fort Gordon, Georgia, 2008-2009. 


\section{Results}

The results of the passive soil-gas survey, seep, and soil samples are presented in this section and used to further delineate the area of contamination related to the NRLF. The results of all samples indicate the aerial extent of the NRLF is larger than suggested in 2007 by initial water-quality sampling.

\section{Passive Soil-Gas Survey}

Of the 29 soil-gas samples installed for this study at the NRLF site (fig. 4; table 1), all had TPH mass greater than the method detection level (MDL) of 0.02 microgram ( $\mu \mathrm{g}$; fig. 5). Higher TPH mass (between 0.1 and $5 \mu \mathrm{g}$ ) was detected in soil-gas samplers near seep 2; these higher detections may be related to the presence of sheet metal from old, oil-fired furnace wastes near this seep. The highest TPH mass (nearly $50 \mu \mathrm{g}$ ) detected in an individual sample was from soil-gas sampler 25 installed in seep 3 (table 1; fig. 5). In September 2007, this seep contained chlorinated organics (AMEC Earth \& Environmental, Inc., written commun., November 2007), so detection of TPH mass in the soil-gas sampler confirms the presence of groundwater contamination by both TPH and chlorinated compounds. Because all 29 soil-gas samplers contained TPH mass at levels greater than the MDL, it is possible that the boundary of the NRLF has not been fully assessed with respect to TPH. The TPH detections in the samples were higher than the reported TPH detections in the two trip blanks ( 0.08 and $0.11 \mu \mathrm{g}$; table 1$)$.

Fewer than half of the soil-gas samplers installed at the NRLF had BTEX mass greater than the MDL of $0.01 \mu \mathrm{g}$ (fig. 6; table 1). Detections of BTEX mass between 0.02 and $0.1 \mu \mathrm{g}$ were in soil-gas samplers near seep 1 and in upgradient areas. The highest soil-gas BTEX mass $(0.83 \mu \mathrm{g})$ was detected in soil-gas sampler 24 on the western side of seep 3. Neither of the two trip blanks had BTEX detections.

Only 5 of the 29 soil-gas samplers had PCE mass greater than the MDL of $0.01 \mu \mathrm{g}$ (fig. 7; table 1). Soil-gas sampler 7 near seep 3 contained the highest PCE mass $(0.73 \mu \mathrm{g}$; table 1$)$. A similarly high PCE mass of $0.15 \mu \mathrm{g}$ was detected in soil-gas sampler 18 in an upgradient area along an unpaved road near the NRLF (fig. 7). Soil-gas samplers between these two locations also contained detections of PCE mass above the MDL, which indicates that the unpaved road may have been used during past waste-disposal activities.

\section{Seep Samples}

Water samples were collected from the three seeps at the NRLF and analyzed for 85 VOCs, 18 SVOCs (including PAHs), and 22 inorganics (tables 2-4). Seep 1 contained concentrations of carbon disulfide (estimated at 0.026 microgram per liter $[\mu \mathrm{g} / \mathrm{L}])$, chloroform $(0.566 \mu \mathrm{g} / \mathrm{L})$, PCE $(0.85 \mu \mathrm{g} / \mathrm{L})$, toluene (estimated at $0.026 \mu \mathrm{g} / \mathrm{L}$ ), and trimethylsilanol $(0.172 \mu \mathrm{g} / \mathrm{L}$; table 2$)$. Seep 2 contained concentrations of acetone (estimated at $0.77 \mu \mathrm{g} / \mathrm{L})$, chloroform $(0.27 \mu \mathrm{g} / \mathrm{L}), \mathrm{PCE}$ $(0.91 \mu \mathrm{g} / \mathrm{L})$, toluene (estimated at $0.027 \mu \mathrm{g} / \mathrm{L}$ ), and trimethylsilanol $(0.12 \mu \mathrm{g} / \mathrm{L}$; table 2$)$. Water from seep 3 was characterized by concentrations of acetone $(59 \mu \mathrm{g} / \mathrm{L}), 2$-butanone (also known as methyl ethyl ketone [MEK] estimated at $1.4 \mu \mathrm{g} / \mathrm{L}$ ), carbon disulfide (estimated at $0.023 \mu \mathrm{g} / \mathrm{L}$ ), chloroform (estimated at $0.014 \mu \mathrm{g} / \mathrm{L}$ ), chloromethane (estimated at $0.14 \mu \mathrm{g} / \mathrm{L}$ ), 4-isopropyl-1-methylbenzene (also known as cymene,

$0.18 \mu \mathrm{g} / \mathrm{L})$, PCE $(0.95 \mu \mathrm{g} / \mathrm{L})$, toluene (estimated at $0.09 \mu \mathrm{g} / \mathrm{L}$ ), pentane $(0.13 \mu \mathrm{g} / \mathrm{L})$, and trimethylsilanol $(0.17 \mu \mathrm{g} / \mathrm{L}$; table 2$)$. Only PCE and toluene have established MCLs for NPDWS, and none of the detections in water from the seeps exceeded these standards.

The detection of VOCs in all three seeps indicates that the lateral extent of groundwater contamination at the NRLF may be larger than that indicated in 2007 (AMEC Earth \& Environmental, Inc., written commun., November 2007) when only one seep (seep 3) was sampled and had detections of VOCs. The data also confirm the presence of a source of PCE in the landfill, as indicated by the results of the passive soil-gas survey (fig. 7; table 1). Moreover, the estimated area of the landfill is at least as large as the area covered during the soil-gas sampling. The presence of trimethylsilanol in all three seeps (table 2) may be related to the degradation of silicone-based materials commonly disposed of in landfills. The PAH compound benzo- $(a)$-pyrene was not detected above the reporting limit of $0.33 \mu \mathrm{g} / \mathrm{L}$ at seeps 1 and 2 (table 3). Benzo- $(a)$-pyrene was detected at an estimated concentration of $0.0134 \mu \mathrm{g} / \mathrm{L}$ at seep 3 (table 3 ).

The water samples also were analyzed for inorganic compounds, including seven of the eight RCRA metals (mercury was excluded as sample collection requires clean methods that were beyond the scope of this investigation). The water sample from seep 1 did not have any detections that exceed standards (table 4). The water sample from seep 2 contained aluminum and iron at 786 and $865 \mu \mathrm{g} / \mathrm{L}$, respectively, both of which exceed the NSDWS MCL (table 4). The water sample from seep 3 contained $492,000 \mu \mathrm{g} / \mathrm{L}$ of iron and $10,700 \mu \mathrm{g} / \mathrm{L}$ of manganese, both of which exceed the NSDWS MCL. The water sample from seep 3 also contained $2.57 \mu \mathrm{g} / \mathrm{L}$ of cadmium, $211 \mu \mathrm{g} / \mathrm{L}$ of copper, and 1,360 $\mu \mathrm{g} / \mathrm{L}$ of zinc, which exceed the Georgia ISWQS; the concentrations of arsenic $(53.2 \mu \mathrm{g} / \mathrm{L})$ and lead $(182 \mu \mathrm{g} / \mathrm{L})$ exceed the NPDWS MCL (table 4).

\section{Soil Samples}

Inorganic concentrations in all four of the soil samples did not exceed the RSLs (table 5). Barium concentrations were, however, two to three times higher than background concentrations reported for South Carolina Coastal Plain sediments (table 5). 
Table 1. Mass of volatile organic compounds detected in soil-gas samples collected from the North Range Road Landfill, Fort Gordon, Georgia, 2008-2009.

[MDL, method detection level; $\mu \mathrm{g}$, micrograms; nd, not detected; $\mathbf{6 8 8 9 4 0}$ and $\mathbf{6 8 8 9 4 1}$ are trip blanks; TPH, total petroleum hydrocarbons; BTEX, benzene, toluene, ethylbenzene, and xylenes; MTBE, methyl tert-butyl ether; DCA, dichloroethane; TCA, trichloroethane; TCE, trichloroethylene; DCE, dichloroethylene; PCE, perchloroethylene; DCB, dichlorobenzene; —, not applicable]

\begin{tabular}{|c|c|c|c|c|c|c|c|c|c|c|}
\hline $\begin{array}{l}\text { Sample } \\
\text { number }\end{array}$ & $\begin{array}{c}\text { Location } \\
\text { number } \\
\text { (fig. } 4 \text { ) }\end{array}$ & $\begin{array}{l}\text { TPH } \\
(\mu g)\end{array}$ & $\begin{array}{c}\text { BTEX } \\
(\mu g)\end{array}$ & $\begin{array}{c}\text { Benzene } \\
(\mu \mathrm{g})\end{array}$ & $\begin{array}{c}\text { Toluene } \\
\text { ( } \mu \mathrm{g})\end{array}$ & $\begin{array}{c}\text { Ethyl- } \\
\text { benzene } \\
(\mu \mathrm{g})\end{array}$ & $\begin{array}{c}m-, p-X y l e n e \\
\text { ( } \mu g)\end{array}$ & $\begin{array}{c}o \text {-Xylene } \\
\text { ( } \mu \mathrm{g})\end{array}$ & $\begin{array}{c}\text { Naphthalene } \\
\text { ( } \mu \mathrm{g})\end{array}$ & $\begin{array}{c}\text { 2-methyl- } \\
\text { naphthalene } \\
(\mu \mathrm{g})\end{array}$ \\
\hline$M D L=$ & & 0.02 & - & 0.01 & 0.01 & 0.01 & 0.01 & 0.01 & 0.01 & 0.01 \\
\hline 688946 & 1 & 0.17 & 0.02 & 0.02 & nd & nd & nd & nd & nd & nd \\
\hline 688947 & 2 & 0.37 & nd & nd & nd & nd & nd & nd & nd & nd \\
\hline 688948 & 3 & 4.82 & 0.02 & 0.02 & nd & nd & nd & nd & nd & nd \\
\hline 688949 & 4 & 0.12 & nd & nd & nd & nd & nd & nd & nd & nd \\
\hline 688950 & 5 & 0.55 & 0.02 & 0.02 & nd & nd & nd & nd & nd & nd \\
\hline 688951 & 6 & 0.24 & 0.04 & 0.04 & nd & nd & nd & nd & nd & nd \\
\hline 688952 & 7 & 0.14 & nd & nd & nd & nd & nd & nd & nd & nd \\
\hline 688920 & 8 & 0.34 & nd & nd & nd & nd & nd & nd & nd & nd \\
\hline 688921 & 9 & 0.20 & 0.02 & 0.02 & nd & nd & nd & nd & nd & nd \\
\hline 688922 & 10 & 0.88 & nd & nd & nd & nd & nd & nd & nd & nd \\
\hline 688923 & 11 & 0.16 & nd & nd & nd & nd & nd & nd & nd & nd \\
\hline 688924 & 12 & 0.44 & nd & nd & nd & nd & nd & nd & nd & nd \\
\hline 688925 & 13 & 0.53 & nd & nd & nd & nd & nd & nd & nd & nd \\
\hline 688926 & 14 & 0.14 & 0.02 & 0.02 & nd & nd & nd & nd & nd & nd \\
\hline 688927 & 15 & 0.47 & 0.02 & 0.02 & nd & nd & nd & nd & nd & nd \\
\hline 688928 & 16 & 0.21 & nd & nd & nd & nd & nd & nd & nd & nd \\
\hline 688929 & 17 & 0.12 & nd & nd & nd & nd & nd & nd & nd & nd \\
\hline 688930 & 18 & 0.20 & nd & nd & nd & nd & nd & nd & nd & nd \\
\hline 688931 & 19 & 0.23 & nd & nd & nd & nd & nd & nd & nd & nd \\
\hline 688932 & 20 & 0.26 & nd & nd & nd & nd & nd & nd & nd & nd \\
\hline 688933 & 21 & 0.12 & nd & nd & nd & nd & nd & nd & nd & nd \\
\hline 688936 & 22 & 0.36 & nd & nd & nd & nd & nd & nd & nd & nd \\
\hline 688937 & 23 & 2.16 & 0.06 & nd & 0.06 & nd & nd & nd & nd & nd \\
\hline 688938 & 24 & 1.55 & 0.83 & nd & 0.83 & nd & nd & nd & nd & nd \\
\hline 688939 & 25 & 48.38 & 0.02 & 0.02 & nd & nd & nd & nd & nd & nd \\
\hline 688942 & 26 & 1.09 & nd & nd & nd & nd & nd & nd & nd & nd \\
\hline 688943 & 27 & 0.58 & 0.04 & nd & 0.04 & nd & nd & nd & nd & nd \\
\hline 688944 & 28 & 0.05 & nd & nd & nd & nd & nd & nd & nd & nd \\
\hline 688945 & 29 & 0.88 & nd & nd & nd & nd & nd & nd & nd & nd \\
\hline 688940 & - & 0.08 & nd & nd & nd & nd & nd & nd & nd & nd \\
\hline 688941 & - & 0.11 & nd & nd & nd & nd & nd & nd & nd & nd \\
\hline
\end{tabular}


Table 1. Mass of volatile organic compounds detected in soil-gas samples collected from the North Range Road Landfill, Fort Gordon, Georgia, 2008-2009.-Continued

[MDL, method detection level; $\mu \mathrm{g}$, micrograms; nd, not detected; $\mathbf{6 8 8 9 4 0}$ and $\mathbf{6 8 8 9 4 1}$ are trip blanks; TPH, total petroleum hydrocarbons; BTEX, benzene, toluene, ethylbenzene, and xylenes; MTBE, methyl tert-butyl ether; DCA, dichloroethane; TCA, trichloroethane; TCE, trichloroethylene; DCE, dichloroethylene; PCE, perchloroethylene; DCB, dichlorobenzene; _, not applicable]

\begin{tabular}{|c|c|c|c|c|c|c|c|c|c|}
\hline $\begin{array}{l}\text { Sample } \\
\text { number }\end{array}$ & $\begin{array}{c}\text { Location } \\
\text { number } \\
\text { (fig. 4) }\end{array}$ & $\begin{array}{l}\text { MTBE } \\
(\mu g)\end{array}$ & $\begin{array}{c}\text { Octane } \\
(\mu g)\end{array}$ & $\mathrm{C}_{11^{\prime}} \underset{(\mu \mathrm{g})}{\mathrm{C}_{13^{\prime}} \& \mathrm{C}_{15}}$ & $\begin{array}{c}\text { Undecane } \\
(\mu \mathrm{g})\end{array}$ & $\begin{array}{c}\text { Tridecane } \\
(\mu \mathrm{g})\end{array}$ & $\begin{array}{c}\text { Pentadecane } \\
(\mu \mathrm{g})\end{array}$ & $\begin{array}{c}\text { Trimethyl } \\
\text { benzenes } \\
(\mu g)\end{array}$ & $\begin{array}{c}1,2,4- \\
\text { Trimethyl } \\
\text { benzene } \\
(\mu \mathrm{g})\end{array}$ \\
\hline$M D L=$ & & 0.01 & 0.01 & & 0.01 & 0.01 & 0.01 & - & 0.01 \\
\hline 688946 & 1 & nd & nd & nd & nd & nd & nd & nd & nd \\
\hline 688947 & 2 & nd & nd & nd & nd & nd & nd & nd & nd \\
\hline 688948 & 3 & nd & nd & nd & nd & nd & nd & nd & nd \\
\hline 688949 & 4 & nd & nd & nd & nd & nd & nd & nd & nd \\
\hline 688950 & 5 & nd & nd & nd & nd & nd & nd & nd & nd \\
\hline 688951 & 6 & nd & nd & nd & nd & nd & nd & nd & nd \\
\hline 688952 & 7 & nd & nd & nd & nd & nd & nd & nd & nd \\
\hline 688920 & 8 & nd & nd & nd & nd & nd & nd & nd & nd \\
\hline 688921 & 9 & nd & nd & nd & nd & nd & nd & nd & nd \\
\hline 688922 & 10 & nd & nd & 0.16 & 0.16 & $\mathrm{nd}$ & nd & nd & nd \\
\hline 688923 & 11 & nd & nd & nd & nd & nd & nd & nd & nd \\
\hline 688924 & 12 & nd & nd & nd & nd & nd & nd & nd & nd \\
\hline 688925 & 13 & nd & nd & 0.12 & 0.11 & 0.01 & nd & nd & nd \\
\hline 688926 & 14 & nd & nd & nd & nd & nd & nd & nd & nd \\
\hline 688927 & 15 & nd & nd & nd & nd & nd & nd & nd & nd \\
\hline 688928 & 16 & nd & nd & nd & nd & nd & nd & nd & nd \\
\hline 688929 & 17 & nd & nd & nd & nd & nd & nd & nd & nd \\
\hline 688930 & 18 & nd & nd & nd & nd & nd & nd & 0.01 & 0.01 \\
\hline 688931 & 19 & nd & nd & 0.02 & 0.02 & nd & nd & nd & nd \\
\hline 688932 & 20 & nd & nd & nd & nd & nd & nd & nd & nd \\
\hline 688933 & 21 & nd & nd & 0.01 & 0.01 & nd & nd & nd & nd \\
\hline 688936 & 22 & nd & nd & 0.01 & 0.01 & $\mathrm{nd}$ & nd & nd & nd \\
\hline 688937 & 23 & nd & 0.01 & nd & nd & nd & nd & nd & nd \\
\hline 688938 & 24 & nd & nd & nd & nd & nd & nd & nd & nd \\
\hline 688939 & 25 & nd & nd & nd & nd & nd & nd & nd & nd \\
\hline 688942 & 26 & nd & nd & nd & nd & nd & nd & nd & nd \\
\hline 688943 & 27 & nd & nd & nd & nd & nd & nd & nd & nd \\
\hline 688944 & 28 & nd & nd & nd & nd & nd & nd & nd & nd \\
\hline 688945 & 29 & nd & nd & 0.03 & 0.02 & 0.01 & nd & nd & nd \\
\hline 688940 & - & nd & nd & nd & nd & nd & nd & nd & nd \\
\hline 688941 & - & nd & nd & nd & nd & nd & nd & nd & nd \\
\hline
\end{tabular}


Table 1. Mass of volatile organic compounds detected in soil-gas samples collected from the North Range Road Landfill, Fort Gordon, Georgia, 2008-2009.-Continued

[MDL, method detection level; $\mu \mathrm{g}$, micrograms; nd, not detected; $\mathbf{6 8 8 9 4 0}$ and $\mathbf{6 8 8 9 4 1}$ are trip blanks; TPH, total petroleum hydrocarbons; BTEX, benzene, toluene, ethylbenzene, and xylenes; MTBE, methyl tert-butyl ether; DCA, dichloroethane; TCA, trichloroethane; TCE, trichloroethylene; DCE, dichloroethylene; PCE, perchloroethylene; DCB, dichlorobenzene; - , not applicable]

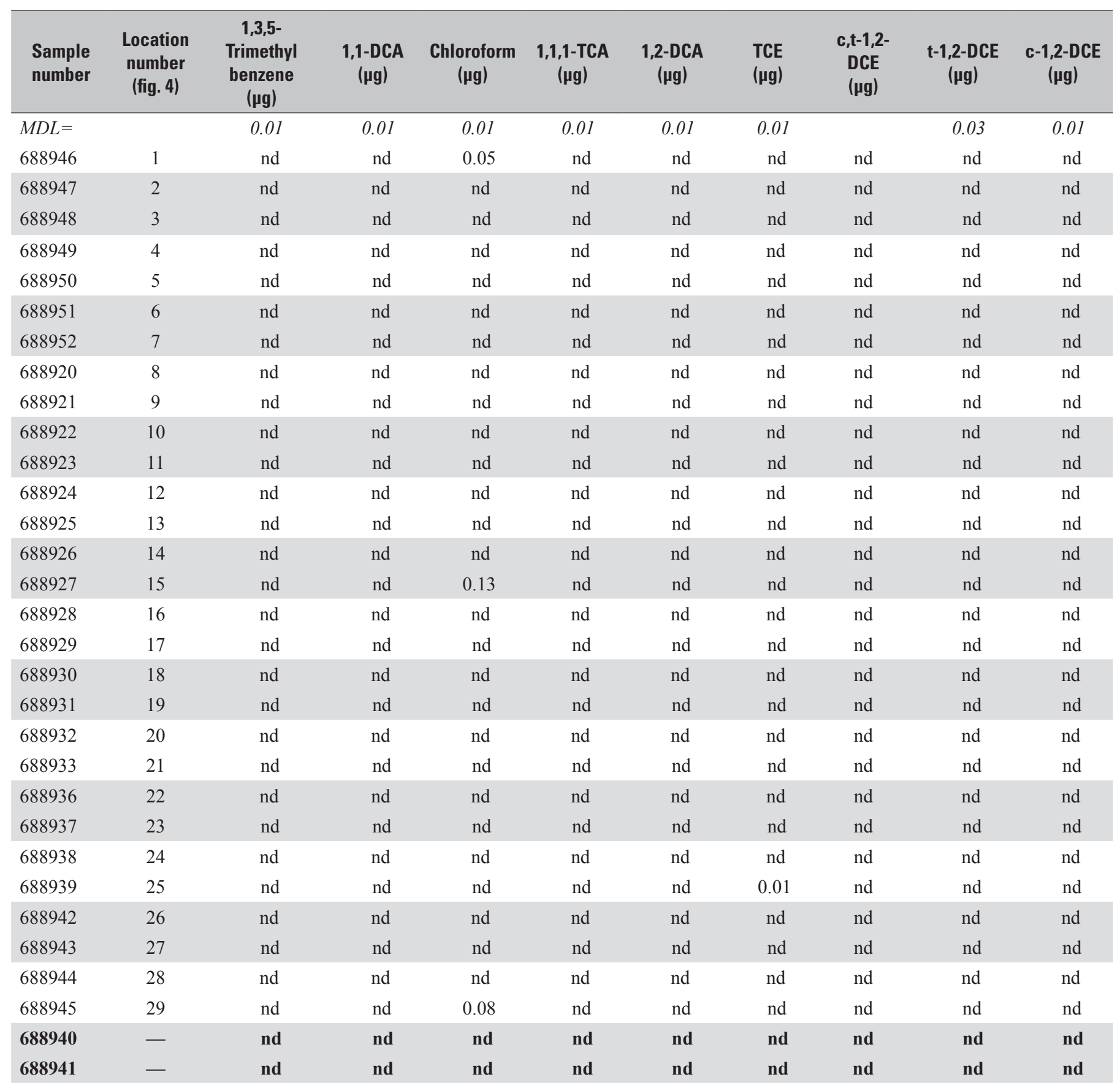


Table 1. Mass of volatile organic compounds detected in soil-gas samples collected from the North Range Road Landfill, Fort Gordon, Georgia, 2008-2009.-Continued

[MDL, method detection level; $\mu \mathrm{g}$, micrograms; nd, not detected; $\mathbf{6 8 8 9 4 0}$ and $\mathbf{6 8 8 9 4 1}$ are trip blanks; TPH, total petroleum hydrocarbons; BTEX, benzene, toluene, ethylbenzene, and xylenes; MTBE, methyl tert-butyl ether; DCA, dichloroethane; TCA, trichloroethane; TCE, trichloroethylene; DCE, dichloroethylene; PCE, perchloroethylene; DCB, dichlorobenzene; - , not applicable]

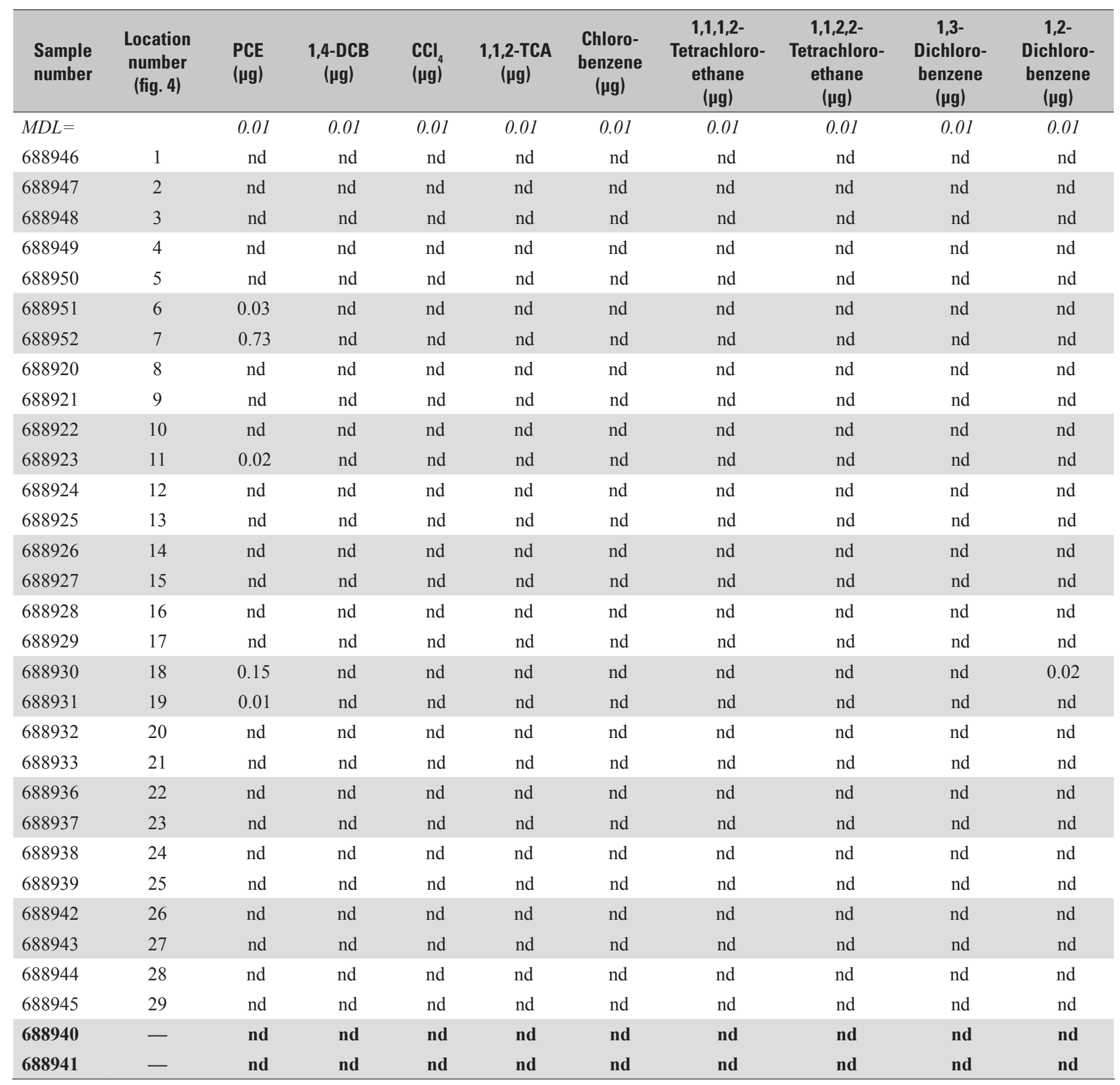




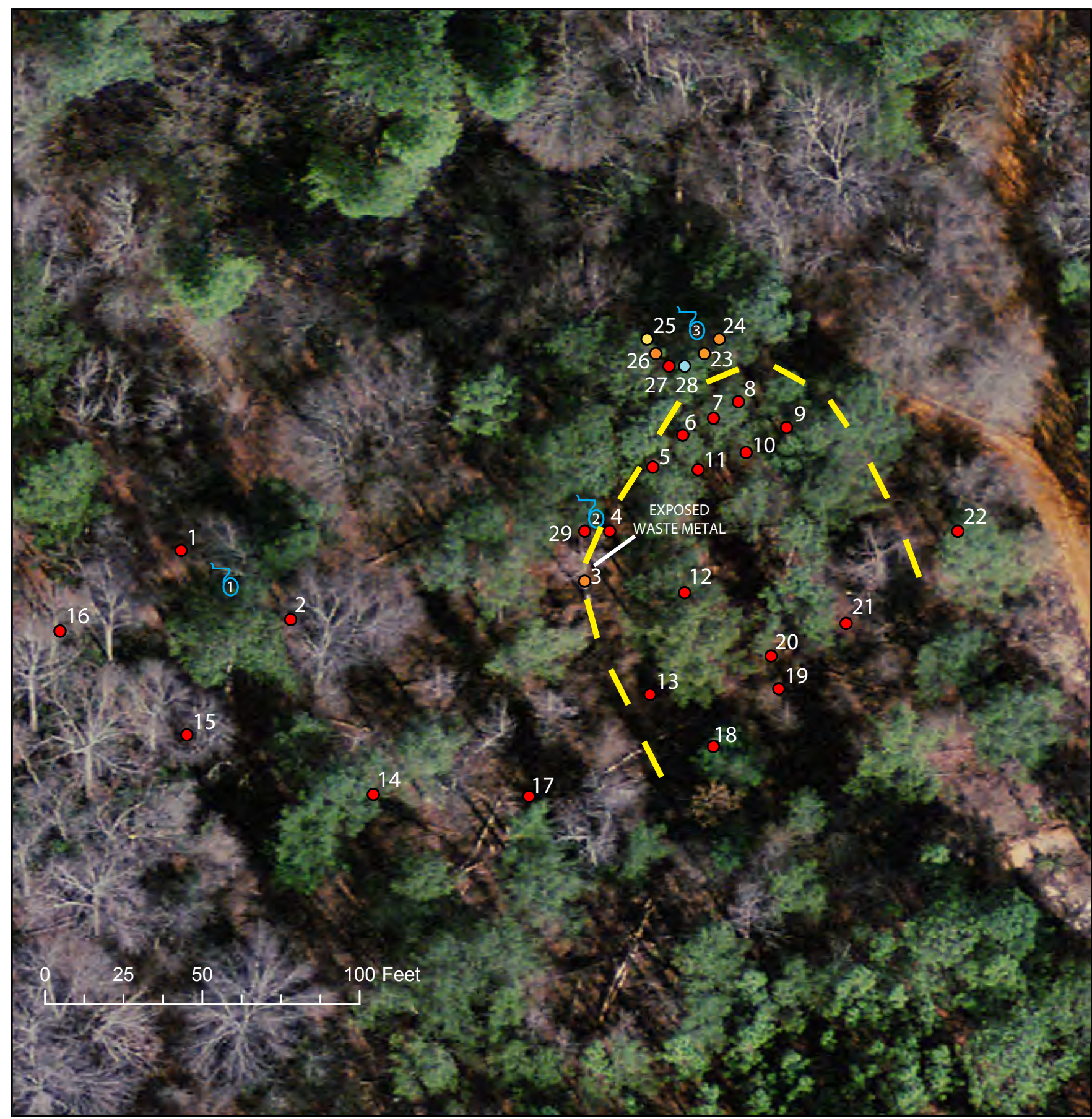

From U.S. Geological Survey digital data

EXPLANATION

APPROXIMATE EXTENT OF BURIED WASTES
(1) SEEP AND NUMBER
$0^{1}$ SOIL-GAS SAMPLER LOCATION AND IDENTIFIER

TOTAL PETROLEUM HYDROCARBONS, AS SOIL GAS (MICROGRAMS)
Greater than 5
Between 1 and 4.9
- Between 0.1 and 0.9
O Between 0.02 and 0.09

Figure 5. Detections of total petroleum hydrocarbon (TPH) mass in 29 soil-gas samplers installed at the North Range Road Landfill, Fort Gordon, Georgia, 2008-2009. Method detection level is 0.02 microgram. 


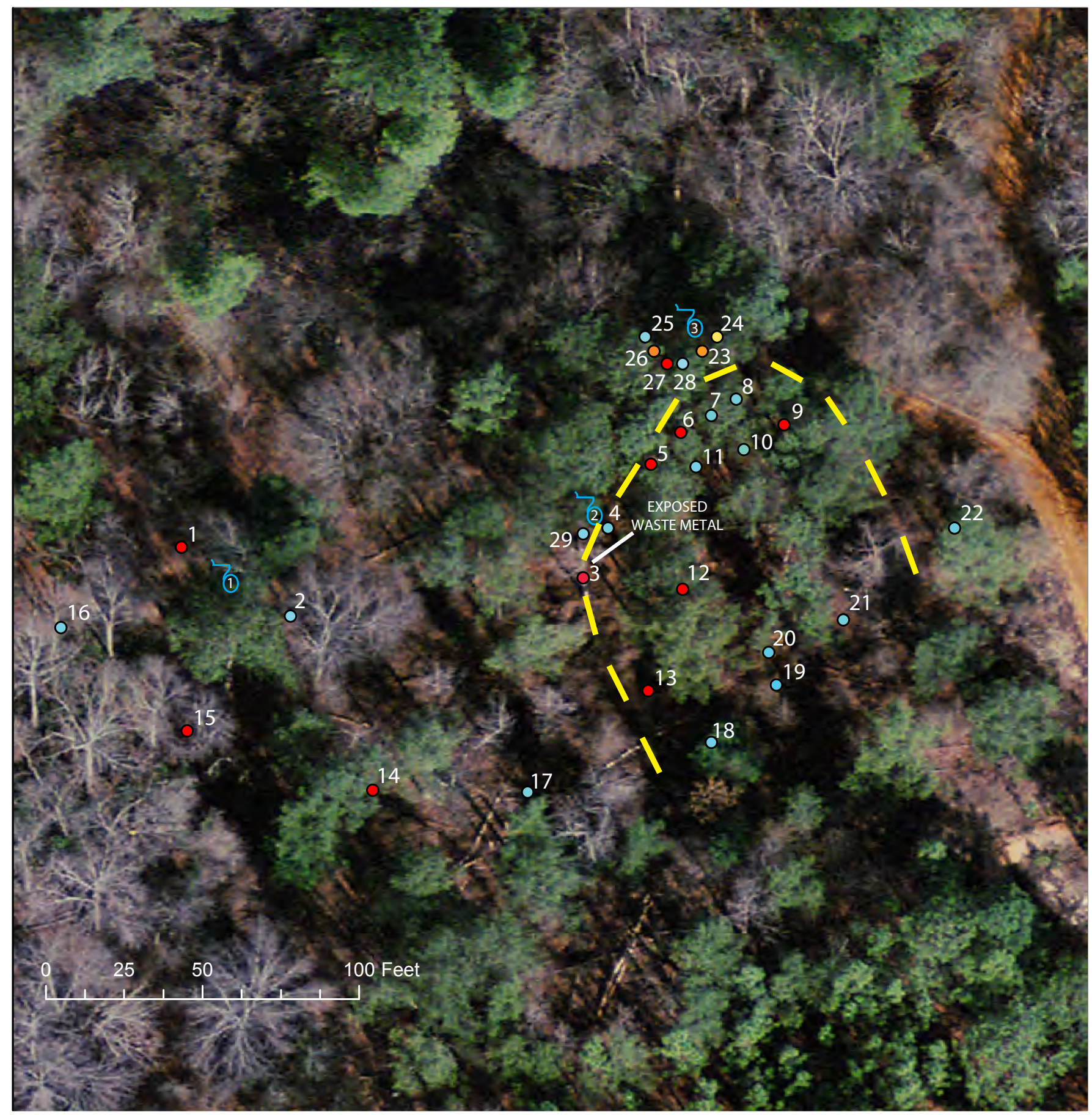

From U.S. Geological Survey digital data

EXPLANATION
APPROXIMATE EXTENT OF BURIED WASTES
(1) SEEP AND NUMBER
$0^{1}$ SOIL-GAS SAMPLER LOCATION AND IDENTIFIER

TOTAL BTEX,

AS SOIL GAS (MICROGRAMS)

O Greater than 0.5

Between 0.11 and 0.49

○ Between 0.02 and 0.1

O Less than 0.02

Figure 6. Detections of benzene, toluene, ethylbenzene, and xylenes (BTEX) mass in 11 soil-gas samplers installed at the North Range Road Landfill, Fort Gordon, Georgia, 2008-2009. Method detection level is 0.01 microgram. 


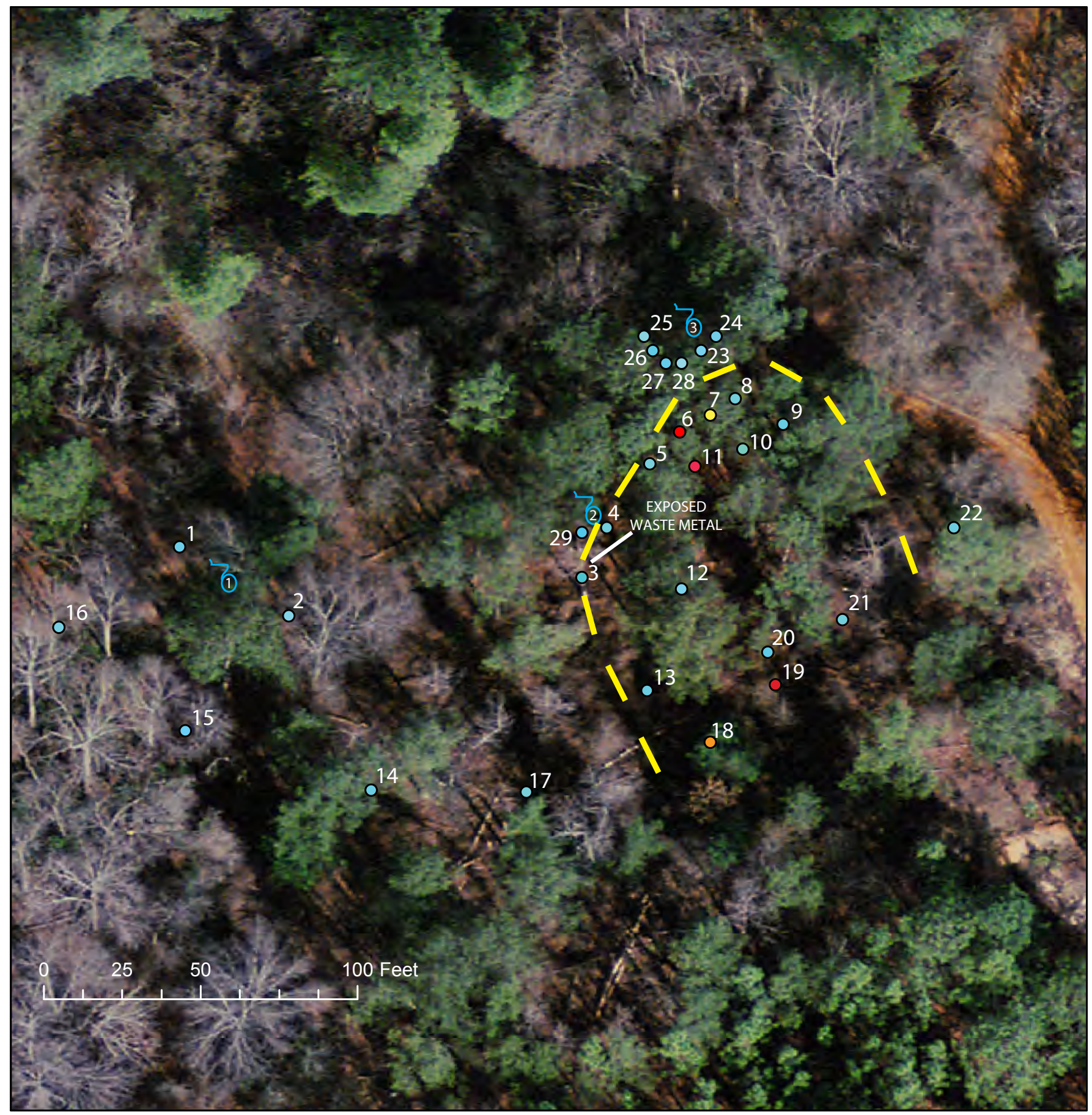

From U.S. Geological Survey digital data

\section{EXPLANATION}

APPROXIMATE EXTENT OF BURIED WASTES

(1) SEEP AND NUMBER
$0^{1}$ SOIL-GAS SAMPLER LOCATION AND IDENTIFIER
PCE, AS SOIL GAS (MICROGRAMS)

O Greater than 0.5

O Between 0.11 and 0.49

○ Between 0.01 and 0.1

- Less than 0.01

Figure 7. Detections of perchloroethylene (PCE) mass in five soil-gas samplers installed at the North Range Road Landfill, Fort Gordon, Georgia, 2008-2009. PCE is also known as tetrachloroethylene. Method detection level is 0.01 microgram. 
Table 2. Organic compounds detected in groundwater discharge from the seeps, collected July 27, 2009.

$[\mu \mathrm{g} / \mathrm{L}$, microgram per liter; MCL, maximum contaminant level; NPDWS, National Primary Drinking Water Standards; E, estimated; <, less than; —, not applicable; TIC, tentatively identified compound]

\begin{tabular}{|c|c|c|c|c|}
\hline \multirow{2}{*}{ Compound } & \multicolumn{3}{|c|}{ Seep number and result ( $\mu \mathrm{g} / \mathrm{L}$ ) } & \multirow{2}{*}{$\begin{array}{c}\text { NPDWS MCL } \\
(\mu \mathrm{g} / \mathrm{L})\end{array}$} \\
\hline & Seep 1 & Seep 2 & Seep 3 & \\
\hline 1,1,1,2-Tetrachloroethane & $<0.04$ & $<0.04$ & $<0.04$ & - \\
\hline 1,1,1-Trichloroethane & $<0.02$ & $<0.02$ & $<0.02$ & 200 \\
\hline 1,1,2,2-Tetrachloroethane & $<0.1$ & $<0.1$ & $<0.1$ & - \\
\hline 1,1,2-Trichloroethane & $<0.06$ & $<0.06$ & $<0.06$ & 5 \\
\hline 1,1,2-Trichlorotrifluoroethane & $<0.04$ & $<0.04$ & $<0.04$ & - \\
\hline 1,1-Dichloroethane & $<0.04$ & $<0.04$ & $<0.04$ & - \\
\hline 1,1-Dichloroethylene & $<0.02$ & $<0.02$ & $<0.02$ & - \\
\hline 1,1-Dichloropropene & $<0.04$ & $<0.04$ & $<0.04$ & - \\
\hline 1,2,3,4-Tetramethylbenzene & $<0.08$ & $<0.08$ & $<0.08$ & - \\
\hline 1,2,3,5-Tetramethylbenzene & $<0.08$ & $<0.08$ & $<0.08$ & - \\
\hline 1,2,3-Trichlorobenzene & $<0.06$ & $<0.06$ & $<0.06$ & - \\
\hline 1,2,3-Trichloropropane & $<0.12$ & $<0.12$ & $<0.12$ & - \\
\hline 1,2,3-Trimethylbenzene & $<0.08$ & $<0.08$ & $<0.08$ & - \\
\hline 1,2,4-Trichlorobenzene & $<0.04$ & $<0.04$ & $<0.04$ & 70 \\
\hline 1,2,4-Trimethylbenzene & $<0.04$ & $<0.04$ & $<0.04$ & - \\
\hline 1,2-Dibromo-3-chloropropane & $<1$ & $<1$ & $<1$ & - \\
\hline 1,2-Dibromoethane & $<0.04$ & $<0.04$ & $<0.04$ & - \\
\hline 1,2-Dichlorobenzene & $<0.02$ & $<0.02$ & $<0.02$ & \\
\hline 1,2-Dichloroethane & $<0.06$ & $<0.06$ & $<0.06$ & 5 \\
\hline 1,2-Dichloropropane & $<0.02$ & $<0.02$ & $<0.02$ & - \\
\hline 1,3,5-Trimethylbenzene & $<0.04$ & $<0.04$ & $<0.04$ & \\
\hline 1,3-Dichlorobenzene & $<0.02$ & $<0.02$ & $<0.02$ & 75 \\
\hline 1,3-Dichloropropane & $<0.06$ & $<0.06$ & $<0.06$ & - \\
\hline 1,4-Dichlorobenzene & $<0.02$ & $<0.02$ & $<0.02$ & - \\
\hline 2,2-Dichloropropane & $<0.06$ & $<0.06$ & $<0.06$ & - \\
\hline 2-Butanone & $<1.6$ & $<1.6$ & $1.4(\mathrm{E})$ & - \\
\hline 2-Chlorotoluene & $<0.02$ & $<0.02$ & $<0.02$ & - \\
\hline 2-Hexanone & $<0.6$ & $<0.6$ & $<0.6$ & - \\
\hline 3-Chloropropene & $<0.08$ & $<0.08$ & $<0.08$ & - \\
\hline 4-Chlorotoluene & $<0.02$ & $<0.02$ & $<0.02$ & - \\
\hline 4-Isopropyl-1-methylbenzene & $<0.06$ & $<0.06$ & 0.18 & - \\
\hline 4-Methyl-2-pentanone & $<0.4$ & $<0.4$ & $<0.4$ & - \\
\hline Acetone & $<4$ & $0.77(\mathrm{E})$ & 59 & - \\
\hline Acrylonitrile & $<0.4$ & $<0.4$ & $<0.4$ & - \\
\hline Benzene & $<0.016$ & $<0.016$ & $<0.016$ & 5 \\
\hline Bromobenzene & $<0.02$ & $<0.02$ & $<0.02$ & - \\
\hline Bromochloromethane & $<0.06$ & $<0.06$ & $<0.06$ & - \\
\hline Bromodichloromethane & $<0.04$ & $<0.04$ & $<0.04$ & - \\
\hline Bromoethene & $<0.12$ & $<0.12$ & $<0.12$ & - \\
\hline Bromoform & $<0.1$ & $<0.1$ & $<0.1$ & - \\
\hline Bromomethane & $<0.4$ & $<0.4$ & $<0.4$ & - \\
\hline Butylbenzene & $<0.08$ & $<0.08$ & $<0.08$ & - \\
\hline Carbon disulfide & $0.026(\mathrm{E})$ & $<0.04$ & $0.023(\mathrm{E})$ & - \\
\hline Chlorobenzene & $<0.02$ & $<0.02$ & $<0.02$ & - \\
\hline
\end{tabular}


Table 2. Organic compounds detected in groundwater discharge from the seeps, collected July 27, 2009.-Continued

$[\mu \mathrm{g} / \mathrm{L}$, microgram per liter; MCL, maximum contaminant level; NPDWS, National Primary Drinking Water Standards; E, estimated; <, less than; —, not applicable; TIC, tentatively identified compound]

\begin{tabular}{|c|c|c|c|c|}
\hline \multirow{2}{*}{ Compound } & \multicolumn{3}{|c|}{ Seep number and result ( $\mu \mathrm{g} / \mathrm{L}$ ) } & \multirow{2}{*}{$\begin{array}{c}\text { NPDWS MCL } \\
(\mu \mathrm{g} / \mathrm{L})\end{array}$} \\
\hline & Seep 1 & Seep 2 & Seep 3 & \\
\hline Chloroethane & $<0.1$ & $<0.1$ & $<0.1$ & - \\
\hline Chloroform & 0.566 & 0.27 & $0.014(\mathrm{E})$ & - \\
\hline Chloromethane & $<0.14$ & $<0.14$ & $0.14(\mathrm{E})$ & - \\
\hline cis-1,2-dichloroethylene & $<0.02$ & $<0.02$ & $<0.02$ & - \\
\hline cis-1,3-dichloropropene & $<0.1$ & $<0.1$ & $<0.1$ & - \\
\hline Dibromochloromethane & $<0.12$ & $<0.12$ & $<0.12$ & - \\
\hline Dibromomethane & $<0.04$ & $<0.04$ & $<0.04$ & - \\
\hline Dichlorodifluoromethane & $<0.1$ & $<0.1$ & $<0.1$ & - \\
\hline Dichloromethane & $<0.04$ & $<0.04$ & $<0.04$ & - \\
\hline Diethyl ether & $<0.12$ & $<0.12$ & $<0.12$ & - \\
\hline Diisopropyl ether & $<0.06$ & $<0.06$ & $<0.06$ & - \\
\hline Ethyl methacrylate & $<0.14$ & $<0.14$ & $<0.14$ & - \\
\hline Ethyl tert-butyl ether & $<0.04$ & $<0.04$ & $<0.04$ & - \\
\hline Ethylbenzene & $<0.04$ & $<0.04$ & $<0.04$ & - \\
\hline Hexachlorobutadiene & $<0.06$ & $<0.06$ & $<0.06$ & - \\
\hline Hexachloroethane & $<0.14$ & $<0.14$ & $<0.14$ & - \\
\hline Isopropylbenzene & $<0.04$ & $<0.04$ & $<0.04$ & - \\
\hline$m$ - and $p$-xylene & $<0.08$ & $<0.08$ & $<0.08$ & - \\
\hline Methyl acrylate & $<0.6$ & $<0.6$ & $<0.6$ & - \\
\hline Methyl acrylonitrile & $<0.2$ & $<0.2$ & $<0.2$ & - \\
\hline Methyl iodide & $<0.8$ & $<0.8$ & $<0.8$ & - \\
\hline Methyl methacrylate & $<0.2$ & $<0.2$ & $<0.2$ & - \\
\hline Naphthalene & $<0.2$ & $<0.2$ & $<0.2$ & - \\
\hline n-propylbenzene & $<0.04$ & $<0.04$ & $<0.04$ & - \\
\hline$o$-ethyltoluene & $<0.02$ & $<0.02$ & $<0.02$ & - \\
\hline$o$-xylene & $<0.04$ & $<0.04$ & $<0.04$ & - \\
\hline sec-butylbenzene & $<0.02$ & $<0.02$ & $<0.02$ & - \\
\hline Styrene & $<0.04$ & $<0.04$ & $<0.04$ & - \\
\hline tert-butyl methyl ether (MTBE) & $<0.1$ & $<0.1$ & $<0.1$ & - \\
\hline tert-butylbenzene & $<0.06$ & $<0.06$ & $<0.06$ & - \\
\hline tert-pentyl methyl ether & $<0.06$ & $<0.06$ & $<0.06$ & - \\
\hline Tetrachloroethylene (PCE) & 0.85 & 0.91 & 0.95 & 5 \\
\hline Tetrachloromethane & $<0.06$ & $<0.06$ & $<0.06$ & - \\
\hline Tetrahydrofuran & $<1.4$ & $<1.4$ & $<1.4$ & - \\
\hline Toluene & $0.026(\mathrm{E})$ & $0.027(\mathrm{E})$ & $0.09(\mathrm{E})$ & 1,000 \\
\hline trans-1,2-dichloroethylene & $<0.018$ & $<0.018$ & $<0.018$ & - \\
\hline trans-1,3-dichloropropene & $<0.1$ & $<0.1$ & $<0.1$ & - \\
\hline trans-1,4-dichloro-2-butene & $<0.4$ & $<0.4$ & $<0.4$ & - \\
\hline Trichloroethylene & $<0.02$ & $<0.02$ & $<0.02$ & 5 \\
\hline Trichlorofluoromethane & $<0.08$ & $<0.08$ & $<0.08$ & - \\
\hline Vinyl chloride & $<0.08$ & $<0.08$ & $<0.08$ & 2 \\
\hline Trimethylsilanol & 0.172 & 0.12 & 0.17 & - \\
\hline Pentane & & & 0.13 (TIC) & - \\
\hline
\end{tabular}


Table 3. Semivolatile organic compounds detected in groundwater discharge from the seeps, collected July 27, 2009.

$[\mu \mathrm{g} / \mathrm{L}$, microgram per liter; ISWQS, In-Stream Water-Quality Standard; MCL, maximum contaminant level for NPDWS (National Primary Drinking Water Standards); $\mathrm{MCL}_{\mathrm{s}}$, maximum contaminant level for NSDWS (National Secondary Drinking Water Standards); E, estimated; <, less than; —, not applicable]

\begin{tabular}{|c|c|c|c|c|c|c|}
\hline Compound & $\begin{array}{c}\text { Seep } 1 \\
(\mu \mathrm{g} / \mathrm{L})\end{array}$ & $\begin{array}{c}\text { Seep } 2 \\
\text { ( } \mu \mathrm{g} / \mathrm{L})\end{array}$ & $\begin{array}{c}\text { Seep } 3 \\
\text { ( } \mu \mathrm{g} / \mathrm{L})\end{array}$ & $\begin{array}{c}\text { Georgia } \\
\text { ISWOS } \\
\text { ( } \mathrm{g} / \mathrm{L} \text { ) }\end{array}$ & $\begin{array}{c}\text { NPDWS } \\
\text { MCL } \\
\text { ( } \mu \mathrm{g} / \mathrm{L})\end{array}$ & $\begin{array}{c}\text { NSDWS } \\
\text { MCL } \\
\text { ( } \mu \mathrm{g} / \mathrm{L})\end{array}$ \\
\hline Acenaphthene & $<0.28$ & $<0.28$ & $<0.28$ & - & - & - \\
\hline Acenapthylene & $<0.3$ & $<0.3$ & $<0.3$ & - & - & - \\
\hline Anthracene & $<0.39$ & $<0.39$ & $<0.39$ & - & - & - \\
\hline Benzo-(a)-anthracene & $<0.26$ & $<0.26$ & $<0.26$ & - & - & - \\
\hline Benzo-(a)-pyrene & $<0.33$ & $<0.33$ & $0.0134(\mathrm{E})$ & - & 0.2 & - \\
\hline Benzo- $(b)$-fluoranthene & $<0.4$ & $<0.4$ & $<0.4$ & - & - & - \\
\hline Benzo-(ghi)-perylene & $<0.4$ & $<0.4$ & $<0.4$ & - & - & - \\
\hline Benzo- $(k)$-fluorathene & $<0.4$ & $<0.4$ & $<0.4$ & - & - & - \\
\hline Chrysene & $<0.33$ & $<0.33$ & $0.0149(\mathrm{E})$ & - & - & - \\
\hline Dibenz $(\mathrm{a}, \mathrm{h})$ anthracene & $<0.4$ & $<0.4$ & $<0.4$ & - & - & - \\
\hline Fluoranthene & $<0.4$ & $<0.4$ & $<0.4$ & - & - & - \\
\hline Fluoranthene & $<0.3$ & $<0.3$ & $0.0179(\mathrm{E})$ & - & - & - \\
\hline Fluorene & $<0.33$ & $<0.33$ & $<0.33$ & - & - & - \\
\hline Indeno $(1,2,3-c d)$ pyrene & $<0.4$ & $<0.4$ & $<0.4$ & - & - & - \\
\hline Naphthalene & $<0.32$ & $<0.32$ & $<0.32$ & - & - & - \\
\hline Nitrobenzene & $<0.21$ & $<0.21$ & $<0.21$ & - & - & - \\
\hline Phenanthrene & $<320$ & $<320$ & $<320$ & - & - & - \\
\hline Pyrene & $<0.35$ & $<0.35$ & & - & - & - \\
\hline
\end{tabular}


Table 4. Inorganic constituents detected in groundwater discharge from the seeps, collected July 27, 2009.

$[\mu \mathrm{g} / \mathrm{L}$, micrograms per liter; ISWQS, In-Stream Water-Quality Standard; MCL, maximum contaminant level for NPDWS (National Primary Drinking Water Standards); $\mathrm{MCL}_{\mathrm{s}}$, maximum contaminant level for NSDWS (National Secondary Drinking Water Standards); E, estimated; <, less than; - , not applicable; pink shading, exceedence of $\mathrm{MCL}_{\mathrm{s}}$; green shading, exceedence of MCL; yellow shading, exceedence of ISWQS]

\begin{tabular}{|c|c|c|c|c|c|c|}
\hline Constituent & $\begin{array}{l}\text { Seep } 1 \\
(\mu \mathrm{g} / \mathrm{L})\end{array}$ & $\begin{array}{c}\text { Seep } 2 \\
\text { ( } \mu \mathrm{g} / \mathrm{L})\end{array}$ & $\begin{array}{c}\text { Seep } 3 \\
\text { ( } \mu \mathrm{g} / \mathrm{L})\end{array}$ & $\begin{array}{c}\text { Georgia } \\
\text { ISWOS } \\
(\mu \mathrm{g} / \mathrm{L})\end{array}$ & $\begin{array}{c}\text { NPDWS } \\
\text { MCL } \\
(\mu \mathrm{g} / \mathrm{L})\end{array}$ & $\begin{array}{l}\text { NSDWS } \\
\text { MCL } \\
(\mu \mathrm{g} / \mathrm{L})\end{array}$ \\
\hline Aluminum & 25.6 & 786 & 51,200 & - & - & 50 to 200 \\
\hline Arsenic & $<0.2$ & $0.16(\mathrm{E})$ & 53.2 & 340 & 10 & - \\
\hline Barium & 4.94 & 11 & 1,070 & - & 2,000 & - \\
\hline Beryllium & $<0.2$ & $<0.2$ & 2.12 & - & 4 & - \\
\hline Cadmium & $<0.06$ & $0.044(\mathrm{E})$ & 2.57 & 2 & 5 & - \\
\hline Calcium & 50 & 459 & 28,300 & - & - & - \\
\hline Chromium & $<0.4$ & 0.91 & 73 & 320 & 100 & - \\
\hline Cobalt & 0.105 & 0.28 & 103 & - & - & - \\
\hline Copper & $<4$ & $<4.0$ & 211 & 7 & - & 1,000 \\
\hline Iron & $8.3(\mathrm{E})$ & 865 & 492,000 & - & - & 300 \\
\hline Lead & $<0.1$ & 2.89 & 182 & 30 & 15 & - \\
\hline Lithium & 0.11 & 0.167 & 5.06 & - & - & - \\
\hline Magnesium & 98 & 147 & 2,790 & - & - & - \\
\hline Manganese & 0.78 & 3.6 & 10,700 & - & - & 50 \\
\hline Molybdenum & $<0.1$ & $<0.1$ & 0.642 & - & - & - \\
\hline Nickel & $0.11(\mathrm{E})$ & 0.43 & 37.4 & 260 & - & - \\
\hline Potassium & $<0.2$ & 200 & 1,530 & - & - & - \\
\hline Selenium & $<0.12$ & 0.17 & 2.81 & - & 50 & - \\
\hline Silver & $<0.06$ & $<0.06$ & 0.734 & - & - & 100 \\
\hline Sodium & 980 & 980 & 810 & - & - & - \\
\hline Strontium & $0.68(\mathrm{E})$ & 4.27 & 212 & - & - & - \\
\hline Zinc & $<4$ & 7 & 1,360 & 65 & - & 5,000 \\
\hline
\end{tabular}


Table 5. Inorganic constituents detected in soil, land surface to 24 inches, collected July 27, 2009.

[USEPA RSL, U.S. Environmental Protection Agency Regional Screening Level, Industrial Soil; mg/kg, milligrams per kilogram; $\mu \mathrm{g} / \mathrm{g}$, micrograms per gram; SC DHEC, South Carolina Department of Health and Environmental Control; <, less than; for soil, $1 \mu \mathrm{g} / \mathrm{g}$ is equivalent to $1 \mathrm{mg} / \mathrm{kg}$, and $1 \mathrm{mg} / \mathrm{kg}$ is equivalent to 1 part per million (ppm); yellow shading, higher than SC background; Note: selenium and mercury were not analyzed; *, Resource Conservation and Recovery Act (RCRA) metal; - , not applicable]

\begin{tabular}{|c|c|c|c|c|c|c|}
\hline Constituent & $\begin{array}{c}\text { Result } \\
0-6 \text { inches } \\
(\mu \mathrm{g} / \mathrm{g})\end{array}$ & $\begin{array}{c}\text { Result } \\
6.1-12 \text { inches } \\
(\mu \mathrm{g} / \mathrm{g})\end{array}$ & $\begin{array}{c}\text { Result } \\
12.1-18 \text { inches } \\
(\mu \mathrm{g} / \mathrm{g})\end{array}$ & $\begin{array}{c}\text { Result } \\
18.1-24 \text { inches } \\
(\mu \mathrm{g} / \mathrm{g})\end{array}$ & $\begin{array}{c}\text { USEPA } \\
\text { RSL } \\
(\mathrm{mg} / \mathrm{kg})\end{array}$ & $\begin{array}{l}\text { SC DHEC } \\
\text { Background } \\
\text { (mg/kg) }\end{array}$ \\
\hline Aluminum & 7,110 & 3,050 & 8,730 & 5,020 & 990,000 & 13,528 \\
\hline Antimony & 0.2 & 0.07 & 0.21 & 0.09 & 410 & - \\
\hline Arsenic* & 1 & $<1$ & $<1$ & $<1$ & 260 & 6.1 \\
\hline Barium* & 111 & 45.1 & 118 & 78.7 & 190,000 & 38 \\
\hline Beryllium & 0.56 & 0.35 & 0.48 & 0.2 & 2,000 & 0.6 \\
\hline Bismuth & 3.19 & 1.4 & 3.3 & 1.82 & - & - \\
\hline Cadmium* & 0.04 & 0.01 & 0.04 & $<0.007$ & 800 & 1 \\
\hline Calcium & 244 & $<100$ & 144 & $<100$ & - & 699 \\
\hline Cerium & 50.6 & 43.1 & 37.6 & 30.7 & - & - \\
\hline Cesium & 0.92 & 0.42 & 1.1 & 0.6 & - & - \\
\hline Chromium* & 8 & 3.4 & 9.3 & 6.5 & $1,500,000$ & 16 \\
\hline Cobalt & 0.48 & 0.19 & 0.44 & 0.32 & 300 & 4 \\
\hline Copper* & 4.9 & 2.4 & 6.5 & 3.1 & 41,000 & 9 \\
\hline Gallium & 2.4 & 1.3 & 2.6 & 1.7 & - & - \\
\hline Iron & 4,220 & 1,220 & 2,640 & 2,300 & 720,000 & 15,608 \\
\hline Lanthanum & 23.9 & 19.8 & 17.1 & 14.9 & - & - \\
\hline Lead* & 8.48 & 3.72 & 8.78 & 4.8 & 800 & 16 \\
\hline Lithium & 6.6 & 2.6 & 7.2 & 3.3 & 2,000 & - \\
\hline Magnesium & 317 & 120 & 348 & 204 & - & 988 \\
\hline Manganese & 58.9 & 18.1 & 35.8 & 34.5 & 23,000 & 120 \\
\hline Molybdenum & 0.28 & 0.1 & 0.27 & 0.2 & 5,100 & - \\
\hline Nickel & 2.1 & 1 & 2.3 & 1.8 & 47,000 & 6 \\
\hline Niobium & 4.2 & 1.6 & 3.8 & 2.9 & - & - \\
\hline Phosphorus & 128 & 65 & 120 & 90.5 & - & - \\
\hline Potassium & 292 & 60.8 & 350 & 146 & - & 856 \\
\hline Rubidium & 5 & 2.2 & 6 & 3.1 & - & - \\
\hline Scandium & 1 & 0.4 & 1.2 & 0.6 & - & - \\
\hline Silver* & $<1$ & $<1$ & $<1$ & $<1$ & 5,100 & 4 \\
\hline Sodium & 93.8 & 32.7 & 84.8 & 45.8 & - & 194 \\
\hline Strontium & 21.2 & 8.9 & 23.4 & 14.8 & 610,000 & \\
\hline Thallium & $<0.08$ & $<0.08$ & $<0.08$ & $<0.08$ & - & 4.5 \\
\hline Thorium & 6.44 & 5.92 & 3.48 & 4.07 & - & - \\
\hline Titanium & 1,640 & 653 & 1,500 & 1,280 & - & - \\
\hline Uranium & 1.13 & 1.18 & 0.93 & 0.9 & - & - \\
\hline Vanadium & 10.2 & 4.1 & 10.6 & 7.3 & 5,200 & - \\
\hline Yttrium & 3.2 & 3.3 & 2.8 & 2.1 & - & - \\
\hline Zinc & 17.8 & 4.6 & 10.3 & 5.8 & 310,000 & 23 \\
\hline
\end{tabular}




\section{Summary}

The U.S. Geological Survey, in cooperation with the Environmental and Natural Resources Management Office of the U.S. Army Signal Center and Fort Gordon, Georgia, assessed soil gas, seeps, and soil for contaminants at the North Range Road Landfill at Fort Gordon, Georgia, from October 2008 to September 2009. All 29 soil-gas samples collected for the study contained total petroleum hydrocarbons (TPH) above the method detection levels. The highest TPH mass detected was in a soil-gas sampler in seep 3. The highest BTEX mass detected was in a soil-gas sampler installed along the western side of seep 3. Some soil-gas samplers had concentrations of the chlorinated organic perchloroethylene (PCE) greater than the method detection level of $0.01 \mu \mathrm{g}$; a soil-gas sampler near seep 3 contained the highest PCE mass of $0.73 \mu \mathrm{g}$. PCE mass above the method detection level also was detected in a soil-gas sampler located upgradient from the seeps.

Water samples collected from the three seeps contained no compounds at levels above the National Primary Drinking Water Standard (NPDWS) maximum contaminant level (MCL). PCE was detected in all three seeps at concentrations between 0.85 microgram per liter $(\mu \mathrm{g} / \mathrm{L}$; seep 1$)$ and $0.95 \mu \mathrm{g} / \mathrm{L}$ (seep 3). Trimethylsilanol also was detected in all three seeps and may be related to the degradation of silicone-based materials commonly found in landfills.

Concentrations of inorganics in seep 1 did not exceed any NPDWS or National Secondary Drinking Water Standard (NSDWS) MCLs. Concentrations of iron and aluminum were detected in seep 2 at 865 and $786 \mu \mathrm{g} / \mathrm{L}$, respectively, and exceed the NSDWS. Concentrations of iron, manganese, and aluminum were detected seep 3 at 492,000, 10,700, and $51,200 \mu \mathrm{g} / \mathrm{L}$, repectively, and exceeded the respective NSDWS MCLs. In seep 3, cadmium, copper, lead, and zinc exceeded the Georgia In-Stream Water Quality Standard (ISWQS) for these inorganics; and arsenic and lead exceeded the NPDWS MCLs for these inorganics. Inorganic concentrations for all four soil samples did not exceed U.S. Environmental Protection Agency values for their regional screening levels. Barium concentrations, however, were two to three times higher than background concentrations reported for similar Coastal Plain sediments in South Carolina.

\section{References Cited}

ASTM International, 2006, Standard guide for soil gas monitoring in the vadose zone: West Conshohocken, PA, ASTM D5314-92 (2001), 36 p.

Georgia Department of Natural Resources, 2007, 391-3-6-.03 Water use classifications and water quality standards: Georgia Environmental Protection Division, Department of Natural Resources, 42 p.

Gregory, M.B., Stamey, T.C., and Wellborn, J.B., 2001, Ecological characterization of streams, and fish-tissue analysis for mercury and lead at selected locations, Fort Gordon, Georgia, June 1999 to May 2000: U.S. Geological Survey Open-File Report 01-203, 14 p.

International Organization for Standardization, 1990, ISO Guide 25. General requirements for the competence of calibration and testing laboratories ( $3^{\mathrm{d}}$ ed.): New York, American National Standards Institute.

South Carolina Department of Health and Environmental Control, 2002, Environmental Surveillance and Oversight Program data report, 2002, accessed February 11, 2010, at http://www.scdhec.gov/environment/envserv/docs/esop datarpt_02.pdf.

U.S. Environmental Protection Agency, 1998, Environmental Technology Verification Report, Soil Gas Sampling Technology: EPA/600/R-98/095.

U.S. Environmental Protection Agency, 2009a, Good Laboratory Practices Standards, compliance monitoring: U.S. Environmental Protection Agency, accessed in October 2009 at http://www.epa.gov/compliance/monitoring/ programs/fifra/glp.html.

U.S. Environmental Protection Agency, 2009b, Regional screening level tables, accessed January 12, 2010, at http:// www.epa.gov/reg3hwmd/risk/human/rb-concentration table/Generic_Tables/index.htm

Williams, L.J., 2007, Hydrogeology and potentiometric surface of the Dublin and Midville aquifer systems in Richmond County, Georgia, January 2007: U.S. Geological Survey Scientific Investigations Map 2982, 1 sheet.

W.L. Gore \& Associates, Inc., 2004, GORE ${ }^{\mathrm{TM}}$ surveys for site assessment \& monitoring, site accessed March 19, 2010, at http://www.gore.com/MungoBlobs/239/659/surveys_ environmental_brochure.pdf. 


\section{Prepared by:}

USGS Science Publishing Network

Raleigh Publishing Service Center

3916 Sunset Ridge Road

Raleigh, NC 27607

For additional information regarding this publication, contact:

James E. Landmeyer

USGS

Stephenson Center, Suite 129

720 Gracern Road

Columbia, SC 29210-7651

email: jlandmey@usgs.gov

Or visit the USGS South Carolina Water Science Center at: http://sc.water.usgs.gov/ 



\section{总}

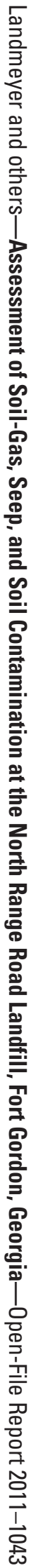

